Utah State University

DigitalCommons@USU

T.W. "Doc" Daniel Experimental Forest

Quinney Natural Resources Research Library,

S.J. and Jessie E.

$11-30-2011$

\title{
Hierarchical controls on runoff generation: Topographically driven hydrologic connectivity, geology, and vegetation
}

Kelsey G. Jensco

Brian L. McGlynn

Follow this and additional works at: https://digitalcommons.usu.edu/docdan

\section{Recommended Citation}

K. G. Jensco, B. L. McGlynn. 2011. Hierarchical controls on runoff generation: Topographically driven hydrologic connectivity, geology, and vegetation. Water Resources Research. 47 (11)

This Article is brought to you for free and open access by the Quinney Natural Resources Research Library, S.J. and Jessie E. at DigitalCommons@USU. It has been accepted for inclusion in T.W. "Doc" Daniel Experimental Forest by an authorized administrator of DigitalCommons@USU.

For more information, please contact

digitalcommons@usu.edu.

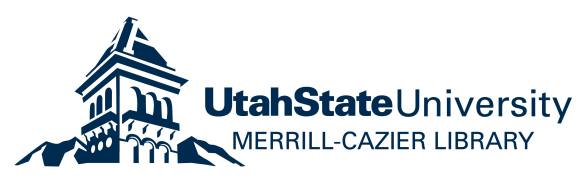




\title{
Hierarchical controls on runoff generation: Topographically driven hydrologic connectivity, geology, and vegetation
}

\author{
Kelsey G. Jencso ${ }^{1}$ and Brian L. McGlynn ${ }^{1}$ \\ Received 14 March 2011; revised 10 October 2011; accepted 12 October 2011; published 30 November 2011.
}

[1] Understanding the relative influence of catchment structure (topography and topology), underlying geology, and vegetation on runoff response is key to interpreting catchment hydrology. Hillslope-riparian-stream (HRS) water table connectivity serves as the hydrologic linkage between a catchment's uplands and the channel network and facilitates the transmission of water and solutes to streams. While there has been tremendous interest in the concept of hydrological connectivity to characterize catchments, few studies have quantified hydrologic connectivity at the stream network and catchment scales with observational data. Here we examine how catchment topography, vegetation, and geology influenced patterns of stream network HRS connectivity and runoff dynamics across 11 nested headwater catchments in the Tenderfoot Creek Experimental Forest (TCEF), MT. This study builds on the empirical findings of Jencso et al. (2009) who found a strong linear relationship $\left(r^{2}=0.91\right)$ between the upslope accumulated area (UAA) and the annual duration of shallow groundwater table connectivity observed across 24 HRS transects (146 groundwater recording wells). We applied this relationship to the entire stream network across 11 nested catchments to quantify the frequency distribution of stream network connectivity through time, and quantify its relationship to catchment-scale runoff dynamics. Each catchment's hydrologic connectivity duration curve (CDC) was highly related to its flow duration curve (FDC) and the slope of the relationship varied across catchments. The slope represents the streamflow yield per unit connectivity $\left(\mathrm{Con}_{\text {yield }}\right)$. We analyzed the slope of each catchment's CDC-FDC relationship or Con $_{\text {yield }}$ (annual, peak, transition, and base flow periods) in multiple linear regression models with common terrain, land cover vegetation, and geology explanatory variables. Significant predictors $(p<0.05)$ across 11 catchments included the ratio of flow path distances and gradients to the creek (DFC/GTC), geology, and a vegetation index. The order and strength of these predictors changed seasonally and highlight the hierarchical controls on headwater catchment runoff generation. Our results highlight direct and quantifiable linkages between catchment topography, vegetation, geology, their topology, and hydrologic dynamics.

Citation: Jencso, K. G., and B. L. McGlynn (2011), Hierarchical controls on runoff generation: Topographically driven hydrologic connectivity, geology, and vegetation, Water Resour. Res., 47, W11527, doi:10.1029/2011WR010666.

\section{Introduction}

[2] The relationship between catchment structure and runoff response remains only partially understood. Difficulties in elucidating this relationship can be attributed to the tremendous internal heterogeneity in key hydrologic variables such as topography, vegetation, geology, and climate. Differences in the relative influence and interactions between these variables can affect runoff processes that occur across a range of space and timescales [Wagener et al., 2007]. There is growing interest in the concept of hydrologic connectivity to describe and quantify catchment runoff generation through time. Many definitions and conceptualizations regarding hydrologic connectivity have recently been pro-

\footnotetext{
${ }^{1}$ Department of Land Resources and Environmental Sciences, Montana State University, Bozeman, Montana, USA.

Copyright 2011 by the American Geophysical Union. 0043-1397/11/2011WR010666
}

posed [Bracken and Croke, 2007; Ali and Roy, 2009; Hopp and McDonnell, 2009; Jencso et al., 2009]. Here we use the term to describe the initiation of a shallow groundwater table across hillslope, riparian, and stream zones [Vidon and Hill, 2004; Ocampo et al., 2006; Jencso et al., 2009]. While the development of water table connectivity across the hillsloperiparian-stream (HRS) continuum is considered a requisite for throughflow [McGlynn and McDonnell, 2003b; Jencso et al., 2009] and solute transport to streams [Carlyle and Hill, 2001; McGlynn and McDonnell, 2003a; Ocampo et al., 2006; Pacific et al., 2010; Jencso et al., 2010], little work has focused on the relative spatio-temporal extent and drivers of connectivity across diverse catchments.

[3] In mountainous catchments, there are often strong relationships between landscape topography and runoff generation [Dunne and Black, 1970; Anderson and Burt, 1978; Beven, 1978; Burt and Butcher, 1985; Savenije, 2010], spatial sources of runoff [Sidle et al., 2000; McGlynn and McDonnell, 2003b], and water residence 
times [McGlynn et al., 2004; McGuire et al., 2005; Tetzlaff et al., 2009]. A specific topographic metric of interest is upslope accumulated area (UAA), which is the amount of land draining to a point in the landscape. Many of the formative hillslope hydrology studies [Hewlett and Hibbert, 1967; Dunne and Black, 1970; Harr, 1977; Anderson and Burt, 1978] observed increased subsurface water accumulation in topographically convergent hillslope areas and in higher upslope accumulated areas (UAA). This historical and more recent research [Jencso et al., 2009] suggests that UAA may be a useful metric for predicting source area connectivity.

[4] Other variables that could influence and even dominate water storage, redistribution, and therefore HRS connectivity initiation and duration include bedrock geology and permeability [Huff et al., 1982; Wolock et al., 1997; Burns et al., 1998; Onda et al., 2001, 2006], soil characteristics [Buttle et al., 2004; Devito et al., 2005; Tetzlaff et al., 2009], and vegetation [Hewlett and Hibbert, 1967; Emanuel et al., 2010]. While all of these factors are likely to influence the redistribution of water and source area hydrologic connectivity and in turn, streamflow response, few empirical studies have explored their combined and hierarchical influence across space and time. This limits our understanding of the spatial and temporal controls on runoff generation both within and across catchments.

[5] A unifying framework describing primary controls on catchment hydrologic response continues to elude hydrologists [Wagener et al., 2007] despite the valuable aforementioned advances. This is partially because of a poor understanding of the linkages between hydrologic connectivity and catchment structure (e.g., topography, geology, and vegetation). This understanding is critical for advances in conceptual understanding and predictive modeling. Progress requires integrated field experimentation from plot to landscape scales to understand the hierarchical influences of these factors across catchment wetness states.

[6] In this study we build on the work of Jencso et al. [2009], who found a strong linear relationship $\left(r^{2}=0.91\right)$ between the hillslope upslope accumulated area (UAA) and the duration of annual hydrologic connectivity observed across the hillslope-riparian-stream (HRS) continuum for 24 transects of shallow groundwater recording wells (UAA sizes ranging from 600 to $46,000 \mathrm{~m}^{2}$ ). This relationship was applied to the local inflows of UAA entering the stream network to estimate the duration of HRS connectivity across the stream network in one headwater catchment of the Tenderfoot Creek Experimental Forest (TCEF) in Montana. The stream network connectivity magnitude varied with the catchment wetness state. The catchment's connectivity duration curve (CDC) represents the fraction of the stream network hydrologically connected to its uplands during the year and was linearly correlated $\left(r^{2}=0.95\right)$ to the annual streamflow duration curve (FDC). The relationship between the connectivity duration curve and the flow duration curve represents the streamflow yield per unit connectivity (connectivity yield; Con $_{\text {yield }}$ ).

[7] To advance previous conceptualizations of connectivity induced runoff generation, we examine how this relationship (CDC:FDC) transfers across 11 adjacent catchments and wetness states. We hypothesize that: (1) the connectivity-runoff relationship parameterized by $\mathrm{Con}_{\text {yield, will vary }}$ across flow states, and (2) variability in Con $_{\text {yield }}$ across catchments is related to differences in catchment structure (topography, geology, and vegetation). We combine high frequency, spatially distributed observations of HRS shallow groundwater connectivity ( 24 well transects; 146 wells) and runoff dynamics (11 gaged catchments) with quantitative landscape analysis of catchment HRS connectivity, topography, geology, and land cover/vegetation characteristics. We address the following questions:

[8] 1. How does the distribution of stream network HRS connectivity relate to runoff dynamics observed at each catchment's outlet?

[9] 2. What factors contribute to the spatial and temporal differences in the connectivity-yield relationship observed across the 11 catchments?

\section{Site Description}

[10] The Tenderfoot Creek Experimental Forest (TCEF) is located in the Little Belt Mountains of Montana (Figure 1). The TCEF consists of 11 nested headwater catchments that drain into Smith River, a tributary to the Missouri River. The climate in the Little Belt Mountains is continental. Annual precipitation in the TCEF averages $880 \mathrm{~mm} \mathrm{yr}^{-1}$ and ranges from 594 to $1050 \mathrm{~mm} \mathrm{yr}^{-1}$ from the lowest to highest elevations. Snowfall composes $75 \%$ of the annual precipitation with snowmelt and peak runoff generally occurring in late May or early June. The lowest runoff occurs in late summer through the winter months. Catchment headwater zones are typified by moderately sloping (average slope $\sim 8^{\circ}$ ) extensive (up to $1200 \mathrm{~m}$ long) hillslopes and variable width $(0.5-52 \mathrm{~m})$ riparian zones. Approaching the main stem of Tenderfoot Creek the streams become more incised, hillslopes become shorter $(<500 \mathrm{~m})$ and steeper (average slope $\sim 20^{\circ}$ ), and riparian areas narrow relative to the catchment headwaters.

[11] The geology is composed of Wolsey shale and Flathead sandstone at higher elevations and transitions to granite gneiss at lower elevations. Geologic strata are differentially permeable with the greatest potential for deeper groundwater exchange at geologic contacts, fractures in the Wolsey shale, and along the weakly cemented laminae in the more permeable sandstone strata [Reynolds, 1995]. General hydraulic conductivities for the three strata likely range from $10^{-9}$ to $10^{-13} \mathrm{~m} \mathrm{~s}^{-1}$ for the granite gneiss, $10^{-9}$ to $10^{-13} \mathrm{~m} \mathrm{~s}^{-1}$ for the shale, and $10^{-4}$ to $10^{-10} \mathrm{~m} \mathrm{~s}^{-1}$ for the sandstone [Freeze and Cherry, 1979]. Soil depths are relatively consistent across the landscape $(0.5-1.0 \mathrm{~m}$ in hillslope positions and $0.5-2 \mathrm{~m}$ in riparian positions) with localized upland areas of deeper soils $(\sim 3 \mathrm{~m})$. The major soil types are characterized as loamy skeletal, mixed typic Cryochrepts located along hillslope positions, and clayey, mixed Aquic Cryboralfs in riparian zones and parks [Holdorf, 1981].

[12] The dominant forms of vegetation include lodgepole pine (overstory; Pinus contorta) and grouse whortleberry (understory; Vaccinium scoparium) in hillslope positions and bluejoint reedgrass (Calmagrostis canadensis) in riparian positions [Farnes et al., 1995; Mincemoyer and Birdsall, 2006]. Previous reports provide more detailed descriptions of TCEF climatic [Farnes et al., 1995], geologic [Reynolds, 1995; Long et al., 1996], and vegetative [Farnes et al., 1995; Mincemoyer and Birdsall, 2006] characteristics. 


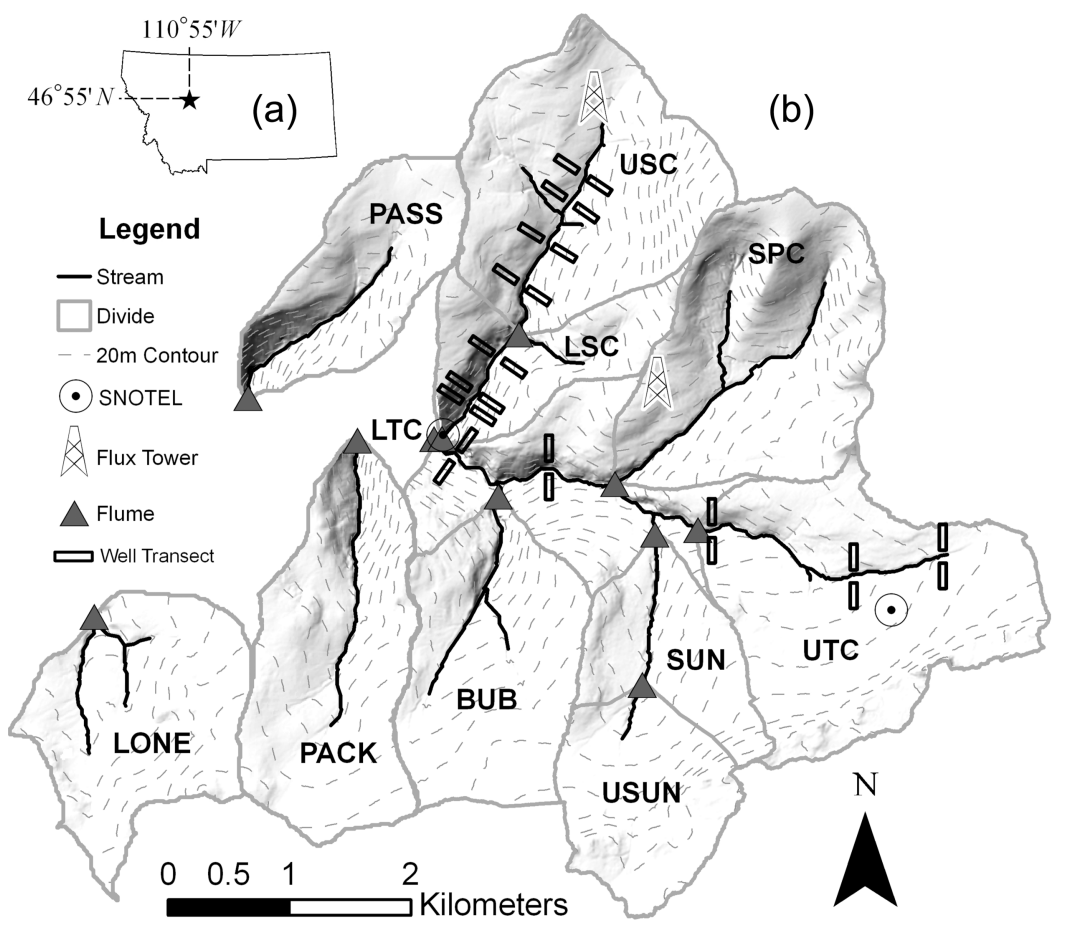

Figure 1. Site location and instrumentation of the TCEF catchment. (a) Catchment location in the Rocky Mountains, Montana. (b) Catchment flumes (the well transects were installed by Jencso et al. [2009]) and SNOTEL instrumentation locations. Transect extents are not drawn to scale.

\section{Research Methodology}

\subsection{Overview of Research Methodology}

[13] We addressed the questions posed in this paper using a geographic information system (GIS) landscape analysis-based approach that couples plot scale observations of hillslope-riparian water table connectivity dynamics, stream network extrapolation of HRS connectivity, and catchment-scale runoff monitoring. The approach consisted of the following steps: (1) quantify terrain indices (TIs) that represent potential topography, vegetation, geology, and land cover influences on runoff generation; (2) quantify each subcatchment's annual HRS connectivity duration curve (CDC) and flow duration curve (FDC) using hourly measurements of transect scale HRS water table measurements and stream discharge; (3) determine the relationship between the CDC and FDC that represents the streamflow yield per unit stream network connectivity (connectivity yield; Con $_{\text {yield }}$ ) across different streamflow and wetness states; and (4) compare intercatchment variability in Con $_{\text {yield }}$ to calculated TIs to determine hierarchical predictors across different streamflow and wetness states. Sections 3.2-3.5 describe these steps in further detail.

\subsection{Terrain Analyses}

\subsubsection{Stream Network Delineation}

[14] Terrain analyses were performed using a $10 \mathrm{~m}$ digital elevation model (DEM) resampled from $1 \mathrm{~m}$ airborne laser swath mapping data (ALSM often referred to as Lidar). The area required for perennial streamflow (creek threshold initiation area) was estimated as 40 ha for Lower Tenderfoot Creek (LTC), Upper Tenderfoot Creek (UTC),
Sun Creek (SUN), Upper Sun Creek (USC), Spring Park Creek (SPC), Lower Stringer Creek (LSC), Middle Stringer Creek (MSC), Passionate Creek (PC), Lonesome Creek (LC), Pack Creek (PC), and 120 ha for Bubbling Creek (BC). The creek threshold initiation area was based on field surveys of channel initiation points in TCEF [Jencso et al., 2009]. The $\mathrm{MD} \infty$ algorithm [Seibert and McGlynn, 2007] was used to derive the flow accumulation grid and related stream network that was verified by field reconnaissance. Once the stream network was delineated, all of the upslope DEM pixels were linked to the stream pixel to which they drained using $\mathrm{MD} \infty$ [Seibert and McGlynn, 2007; Grabs et al., 2010]. The $\mathrm{MD} \infty$ algorithm assumes that the direction of subsurface flow follows surface topography.

\subsubsection{Catchment and Hillslope Scale Terrain Indices}

[15] Terrain indices (TIs) were calculated as distributed values for each $10 \mathrm{~m}^{2}$ pixel across each catchment and discretely for each hillslope contributing area entering the stream network. These indices are quantitative metrics representing the potential influence of catchment surface topography on hydrologic response. Distributed catchment TIs included: slope, aspect, the gradient along the flow path from each pixel to the creek, the distance from each pixel to the creek, the ratio of the flow path length and the gradient from each pixel to the creek (DTC/GTC; as a surrogate for the travel time) along each flow path, the elevation of each pixel above the creek [Rennó et al., 2008; Nobre et al., 2011], and the percentage of catchment riparian and hillslope area. Riparian areas were delineated as any landscape position $<2 \mathrm{~m}$ above the stream network following flow paths to the creek [Grabs et al., 2010]. Jencso et al. [2009] corroborated this method through field-based 
mapping of 90 riparian cross sections. Table 1 describes each of the distributed terrain indices and how they were calculated. We determined median values of each distributed TI for all 11 of the TCEF catchments.

[16] Stream network terrain analyses included quantification of lateral inflows of UAA and the ratio of hillslope and riparian accumulated area (riparian buffering index) entering each stream pixel (a surrogate for the volumetric buffering of hillslope inputs [McGlynn and Seibert, 2003; Jencso et al., 2010]) separately for the left and right sides of the stream. Mean values of each TI across the lateral contributing area of the left and right sides of the stream network were also calculated. These analyses incorporated the methodology developed by Grabs et al. [2010] which determines the orientation of the stream banks relative to the stream, and combines this with standard flow accumulation algorithms to quantify the value of the accumulated TI. Left and right side separations were implemented within the open source software SAGA GIS [Böhner et al., 2008]. 3.2.3. Geology and Vegetative Cover

[17] In addition to the metrics that describe shallow subsurface water redistribution, we calculated indices for

Table 1. Terrain Predictor Variables Extracted From Landscape Analysis

\begin{tabular}{|c|c|}
\hline Terrain Predictor & Description \\
\hline $\begin{array}{l}\text { Local inflows of } \\
\text { UAA }\end{array}$ & $\begin{array}{l}\text { Upslope accumulated area on the left and right } \\
\text { stream sides. Used as a proxy for shallow water } \\
\text { redistribution and HRS hydrologic connectivity. }\end{array}$ \\
\hline RBI & $\begin{array}{l}\text { Riparian buffering (ratio of hillslope and riparian } \\
\text { area) on the left and right stream sides. A proxy } \\
\text { for volumetric and chemical buffering of hill- } \\
\text { slope inputs. }\end{array}$ \\
\hline Slope & Slope of each DEM pixel. \\
\hline Aspect & Azimuth of each DEM pixel. \\
\hline DFC & Flow path distance from the stream. \\
\hline GTC & Gradient along a flow path to the stream. \\
\hline $\mathrm{DFC} / \mathrm{GTC}$ & Ratio of flow path length and gradient. \\
\hline EAC & $\begin{array}{l}\text { Elevation of a DEM cell above the stream cell it } \\
\text { flows into. }\end{array}$ \\
\hline Riparian Area (\%) & $\begin{array}{l}\text { Percentage of riparian area in each catchment. } \\
\text { Riparian area was estimated to be the limit of } \\
\text { saturated overland flow generation. }\end{array}$ \\
\hline Hillslope Area (\%) & $\begin{array}{l}\text { Percentage of hillslope area in each catchment. } \\
\text { Hillslope area was computed as the difference } \\
\text { between total catchment area and riparian area. }\end{array}$ \\
\hline Geology $(\%)$ & $\begin{array}{l}\text { Areal coverage for each geologic stratum in TCEF } \\
\text { (granite gniess [GG], flathead sandstone [SS], } \\
\text { wolsey shale [WS], and biotite hornblende quartz } \\
\text { monzonite [BHQM)]). }\end{array}$ \\
\hline $\begin{array}{l}\text { Geology } \\
>5000 \mathrm{~m}^{2}(\%)\end{array}$ & $\begin{array}{l}\text { The percentage of each geologic stratum that is } \\
\text { overlain by UAA sizes }<5000 \mathrm{~m}^{2} \text {. This threshold } \\
\text { was selected to locate UAA positions that would } \\
\text { have longer duration shallow groundwater table } \\
\text { connectivity; on the basis of the relationship } \\
\text { observed by Jencso et al. [2009]. }\end{array}$ \\
\hline $\mathrm{VEG}_{\mathrm{H}}$ & $\begin{array}{l}\text { Catchment tree height }(>1 \mathrm{~m} \text { threshold). Tree } \\
\text { heights were calculated as the difference between } \\
\text { the first and second returns of Lidar data. }\end{array}$ \\
\hline Forest cover $(\%)$ & $\begin{array}{l}\text { Percentage of catchment covered by trees taller } \\
\text { than } 1 \mathrm{~m} \text {. Vegetation height was calculated as the } \\
\text { difference between the first and second returns of } \\
\text { Lidar data. }\end{array}$ \\
\hline $\mathrm{VEG}_{\mathrm{B}}$ & $\begin{array}{l}\text { Vegetation height multiplied by vegetation density. } \\
\text { A metric of the relative forested biomass within } \\
\text { each catchment. }\end{array}$ \\
\hline
\end{tabular}

catchment geology and vegetative cover. Catchment geology was quantified as the areal percentage of each underlying strata. These included Porphyritic Rhyodacite, Wolsey shale, Flathead sandstone, and granite Gneiss. Additionally, we determined the percentage of the geologic stratum that coincided with UAA $>5000 \mathrm{~m}^{2}\left(\%\right.$ Geology $\left.y_{U A A}>5000 \mathrm{~m}^{2}\right)$. This UAA threshold was selected as indicative of the portions of the landscape that would be expected to have a more sustained shallow groundwater table [Jencso et al., 2009] (see below for more detail).

[18] Vegetation heights were calculated as the difference between first and last returns (i.e., the difference between the top of the canopy and the ground surface) of the $1 \mathrm{~m}$ ALSM Lidar data. Similar Lidar-derived vegetation height indices have been shown to accurately represent groundbased measurements of vegetation height [Dubayah and Drake, 2000; Lefsky et al., 2002]. Vegetation heights $>1 \mathrm{~m}$ were classified "conifers." From the conifer coverage we estimated the median tree height $\left(\mathrm{VEG}_{\mathrm{H}}\right)$ within each subcatchment and percentage of the catchment covered by trees (percentage of forest cover; height $>1 \mathrm{~m}$ ). A secondary index, median height ${ }^{*}$ density $\left(\mathrm{VEG}_{\mathrm{B}}\right)$, was also calculated as a relative measure of biomass across the landscape.

\subsection{Physical Hydrology}

[19] Jencso et al. [2009] collected high frequency HRS groundwater table connectivity observations along 24 HRS transects spanning the range of hillslope UAA sizes (699$46,000 \mathrm{~m}^{2}$ ) within the TCEF. At a minimum, groundwater wells were installed across each transect's hillslope (2-5 m above the break in slope), toeslope (the break in slope between riparian and hillslope positions), and riparian position (1-2 $\mathrm{m}$ from the stream). All wells were screened from $10 \mathrm{~cm}$ below the ground surface to their completion depths at the bedrock interface. Groundwater levels in each well were recorded with Tru Track Inc. capacitance rods $( \pm 1 \mathrm{~mm}$ resolution) at hourly intervals for the 2007 water year. In this study, we define shallow groundwater as saturation at and above the soil-bedrock interface and conversely, deeper groundwater as saturation below the soil-bedrock interface. The shallow groundwater wells do not measure groundwater dynamics below the soil-bedrock interface. Hydrologic connectivity between HRS zones was inferred from the presence of shallow groundwater measured in well transects spanning the hillslope, toeslope, and riparian positions.

[20] Runoff was recorded in each of the 11 catchments using either Parshall or H-Flumes installed by the United States Forest Service (USFS) (Figure 1). The stage in each flume was measured at hourly intervals with Tru Track Inc. water level recorders and every $15 \mathrm{~min}$ by USFS float potentiometers. Manual measurements of both groundwater well levels (electric tape) and flume stage (visual stage readings) were conducted bi-weekly during the summer months and monthly during the winter to corroborate capacitance rod measurements.

\subsection{Stream Network Connectivity}

[21] HRS connectivity for each subcatchment's stream network was estimated based on the relationship quantified by Jencso et al. [2009], between lateral inflows of UAA to each stream pixel and observed HRS water year connectivity durations (Figure 2). The cumulative duration of HRS 

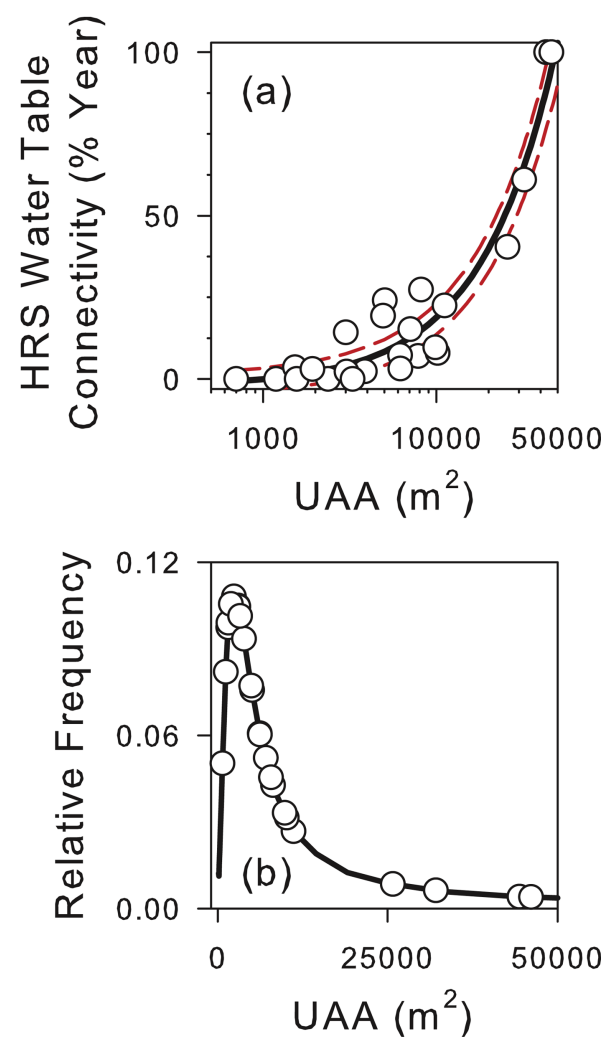

Figure 2. (a) The linear relationship between the local inflows of hillslope UAA and HRS shallow groundwater connectivity duration observed by Jencso et al. [2009]. This relationship was applied to each $10 \mathrm{~m}$ HRS source area assemblage to model stream network hydrologic connectivity. (b) The location of each of the 24 HRS well transects hillslope UAA within the stream network frequency distribution of hillslope UAA.

connectivity was regressed against the size of each transects hillslope UAA (equation $\left.(1) ; r^{2}=0.92\right)$ to develop a relationship for each $10 \mathrm{~m}$ source area assemblage along the network for each side of the stream

$$
\% \text { Yr Connected }=(0.00002 * \mathrm{UAA}-0.0216) .
$$

For the purposes of this study, we refer to UAA size $\left(\mathrm{m}^{2}\right)$ as a surrogate for the duration of groundwater table connectivity between HRS zones as demonstrated with the above regression equation (1). Larger UAA sizes indicate longer periods of water year connectivity duration, and smaller UAA sizes generally represent transient HRS water table connections that occur only during the largest snowmelt events (Figure 2). We applied this relationship to the local inflows of UAA for each stream pixel (on the left and right stream sides) across the 11 TCEF catchments to estimate the frequency of HRS connectivity through time.

\subsection{Stream Network Connectivity and Runoff Comparisons}

3.5.1. Stream Network Connectivity-Runoff Distributions and "Connectivity Yield"

[22] The exceedance probability of each catchment's stream network connectivity fraction (connectivity duration curve; CDC) was compared to its annual flow duration curve (FDC) to assess the relationship between spatio-temporal patterns of connectivity and the magnitude of stream discharge through time (Figure 3). The FDCs were derived from 8762 hourly observations of runoff at each subcatchment flume for the 2007 water year. Catchment CDCs were derived from the combined $10 \mathrm{~m}$ left and right stream bank connectivity frequencies (3108-344, $10 \mathrm{~m}$ cells; depending on the catchment) for the 2007 water year. Both the CDC and FDC distributions were binned in $1 \%$ increments (100 bins).

[23] Annual correlation coefficients and the rate of change between estimated stream network connectivity and runoff were determined by plotting each $1 \%$ increment of the catchment CDCs against their respective FDCs (Figure 4c). This relationship can be considered the "connectivity yield" $\left(\mathrm{Con}_{\text {yield }}\right)$ for each catchment, or the rate of change of runoff with respect to increasing stream network HRS connectivity. To ascertain Con $_{\text {yield }}$ across flow states, the annual CDCFDC relationship was separated into wet (highest runoff $0 \%-10 \%$ of the year), transition (hydrograph rise and recession; $10 \%-50 \%$ of the year), and dry periods (base flow $50 \%-100 \%$ of the year) using linear, exponential, and logarithmic fits, respectively. The slope of each of these relationships $\left(\mathrm{Con}_{\text {yield }}\right)$ was used to assess the runoff response to connectivity dynamics across each of the 11 catchments.

3.5.2. Univariate and Multiple Linear Assessment of Factors That Influence Connectivity Yield

[24] Relationships between topography, source area connectivity, and runoff generation were assessed using univariate regression and forward stepwise multiple regression analyses within the statistical program $\mathrm{R}[R$ Development Core Team, 2008]. Multiple linear regression is a classic approach to fit a multivariate linear function between a response variable and a set of more than one predictor. A multivariate linear function (equation (2)) between response variable $Y$ and predictors $X_{1}, X_{2}, \ldots, X_{n}$ is composed of an intercept and coefficients $\beta_{1}, \beta_{2}, \ldots, \beta_{n}$ corresponding to each of the predictors. The intercept and the coefficients are estimated through a regression procedure:

$$
Y=\beta_{0}+\beta_{1} X_{1}+\beta_{2} X_{2}+\ldots+\beta_{n} X_{n} .
$$

Median values of all TI and geologic-vegetative indices were regressed against $\mathrm{Con}_{\text {yield }}$ at annual, peak, transitional, and base flow periods to assess variables that could partially explain differences in the slope of the relationship between HRS hydrologic connectivity and runoff magnitude across catchments. Model goodness of fit for each possible combination of variables was assessed via Akaike's information criterion (AIC). The TI predictors were dropped or added according to a respective increase or decrease in the AIC for each modeled time period. The TIs selected for each regression equation were those that were significant $(p \leq$ $0.05)$ in explaining the differences in the slope of the relationship between the CDC and FDC across catchments and time periods.

\section{Results}

\subsection{Catchment Connectivity, Runoff, and Con yield $_{\text {. }}$}

[25] Figure 3 depicts the frequency distribution of HRS connectivity durations (equation (1)) across each catchment's 


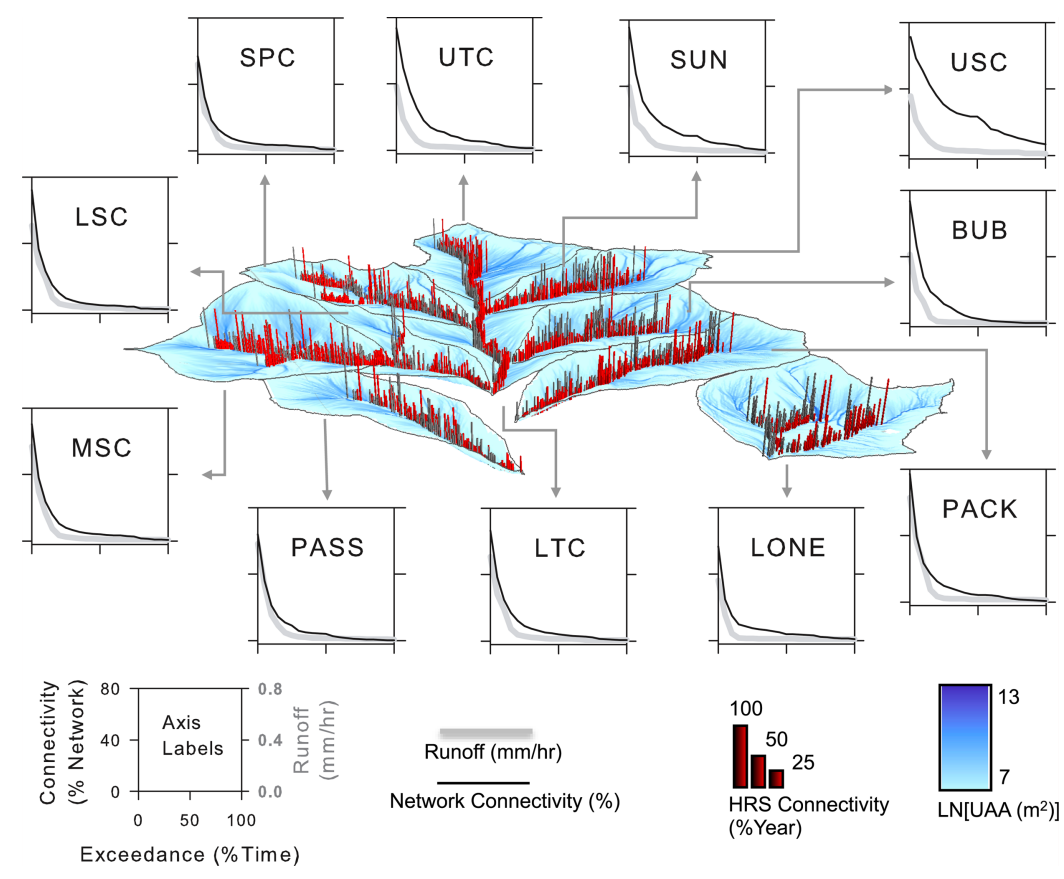

Figure 3. Comparison of the TCEF catchment connectivity duration curves (CDC) to the annual flow duration curves (FDC). CDCs were derived from the frequency distribution of HRS water table connectivity at each $10 \mathrm{~m}$ pixel (both sides) along the stream network. FDCs were derived from hourly runoff values for the 2007 water year ( 8732 values). Stream network connectivity magnitude is represented by the black line and left axis. Runoff magnitude in each plot is represented by the gray line and right axis. The periods of lowest runoff are associated with the lowest connectivity that occurs among the largest UAA values. Larger magnitude runoff is associated with increasing hydrologic connectivity across subsequently smaller stream network UAA values (increasing from large to small).

stream network and a comparison of stream network connectivity (CDC) to the flow duration curve (FDC) for the 2007 water year. Connectivity varied across catchments as a result of stream network UAA distributions. Catchments with a high frequency of longer duration connectivity values included USUN, PACK, SUN, UTC, and USC. Peak stream network connectivity in these catchments ranged from $80 \%$ to $71 \%$ during snowmelt and decreased to between $10 \%$ and $2 \%$ during the driest periods (Figure $4 \mathrm{a}$ ). A higher frequency of transient or shorter duration connectivity was observed in catchments with more topographic convergence and divergence in the landscape and smaller median UAA sizes. These included LSC, LTC, PASS, BUB, SPC, and LONE. In these catchments, peak connectivity was between $70 \%$ and $56 \%$ and decreased to between $1.8 \%$ and $1 \%$ during dry periods (Figure $4 a$ ).

[26] Runoff dynamics were also variable across catchments. This is exemplified by the differences in the shape and inflection of the FDCs across time (Figures 3 and $4 \mathrm{~b}$ ). Catchments with the lowest magnitude runoff during peak flow ( $0 \%$ exceedance) included USC, UTC, SUN, LONE, and BUB. Here maximum runoff values were between 0.3 and $0.41 \mathrm{~mm} \mathrm{~h}^{-1}$. A higher magnitude runoff between 0.45 and $0.63 \mathrm{~mm} \mathrm{~h}^{-1}$ was characteristic of SPC, LTC, MSC, PACK, PASS, and LSC (in increasing order). During the driest time periods $(100 \%$ exceedance) the general order of this relationship shifted. USC, UTC, SUN, and PACK exhibited generally higher runoff (between 0.016 and $0.008 \mathrm{~mm} \mathrm{~h}^{-1}$ ) relative to LONE, SPC, PASS, MSC, LSC, LTC, and BUB (between 0.007 and $0.002 \mathrm{~mm} \mathrm{~h}^{-1}$ ).

[27] The slope of the relationship between fractional network connectivity and runoff ( $\left.\mathrm{Con}_{\text {yield }}\right)$ varied across catchments for each flow state (Figures 4c, 5, 6, 7, and 8, inset panels). Table 2 includes catchment $\mathrm{Con}_{\text {yield values and }}$ correlation coefficients for the annual, wet, transition, and dry time periods. The catchment relationships were relatively consistent across the annual, peak, and transition time periods. SUN, USC, and UTC had consistently lower slopes relative to LONE, LTC PACK, MSC, BUB, LSC,

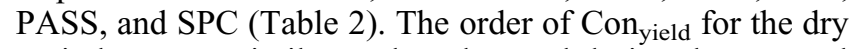
period was not similar to that observed during the wet and transition periods. PASS, LONE, BUB, LSC, SPC, and PACK exhibited lower Con $_{\text {yield }}$ relative to SUN, LTC, MSC, USUN, and UTC (Table 2).

\subsection{Predictors of Con yield $_{\text {Across Catchments }}$}

[28] To assess landscape variables that could affect Conyield across catchments and time periods, we used median values of each TI distribution (Table 1) versus Con $_{\text {yield }}$ in multiple linear models for annual, peak, transitional, and base flow periods (Table 2). There was significant correlation among median values of the retained landscape predictor variables (Table 3 ). In the following paragraphs we describe the significant univariate predictors and their combined explanatory power within forward stepwise multiple regression models. 

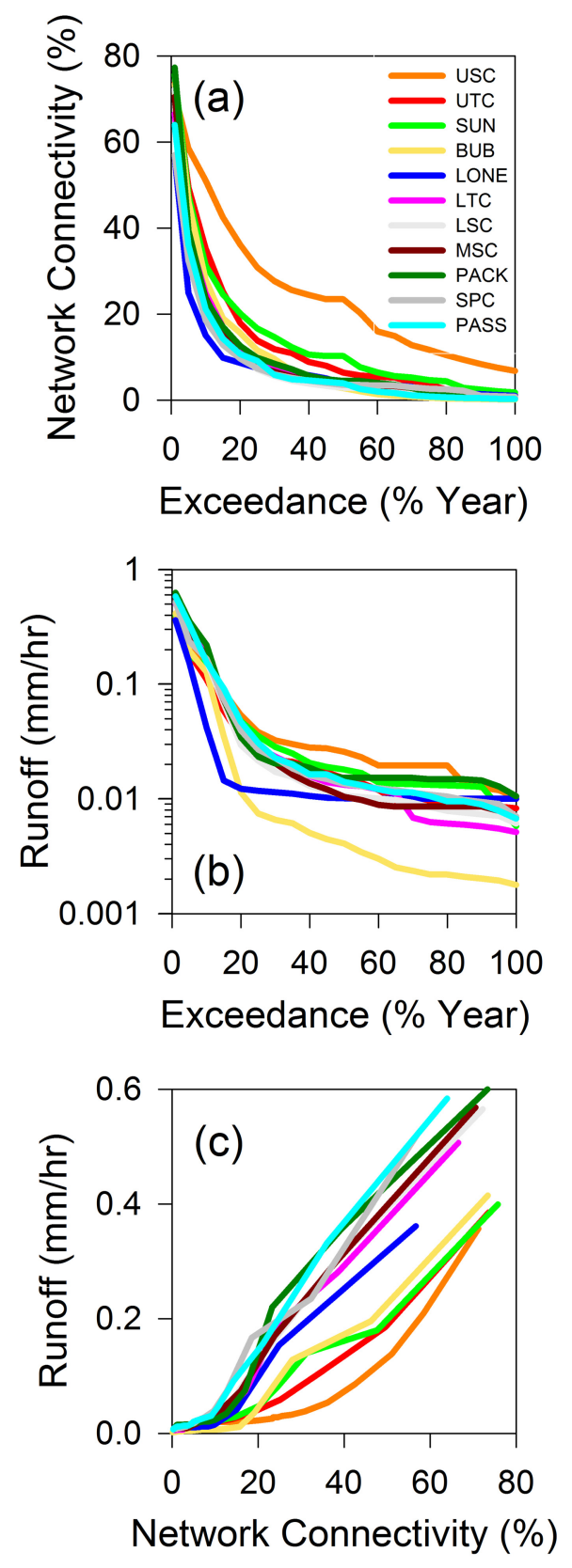

Figure 4. The 11 TCEF catchments (a) connectivity duration curves, (b) flow duration curves, and (c) the stream network connectivity duration curves plotted against the annual flow duration curves at $1 \%$ increments. The slope of this relationship represents the connectivity yield $\left(\mathrm{Con}_{\text {yield }}\right)$ or change in runoff magnitude per unit of stream network connectivity for each catchment.

[29] Significant univariate predictors and their relationships to $\mathrm{Con}_{\text {yield }}$ are shown in Figure 9. Metrics derived from surface topography that explained a significant proportion of the variability in Con $_{\text {yield }}$ included the DFC, GTC, and DFC/GTC. The ratio of the DTC and GTC explained the most variability and resulted in the most parsimonious model fit. Increasing DFC/GTC ratios were correlated to decreasing $\mathrm{Con}_{\text {yield }}$ across the annual, peak, and transition time periods (Figure 9a; $r^{2}=0.87,0.82$, and
0.92 , respectively, with $p<0.05$ ). A significant relationship between the DFC/GTC and Con $_{\text {yield }}$ did not exist during the base flow period $\left(r^{2}=0.45, p>0.05\right)$. Increasing median $\mathrm{VEG}_{\mathrm{H}}$ values were correlated to decreasing Con yield $_{\text {coeffi- }}$ cients across the annual, peak, and transition time periods (Figure $9 \mathrm{~b} ; r^{2}=0.87,0.72$, and 0.75 , respectively, with $p<0.05)$. During the dry time period, the strength of this relationship decreased $\left(r^{2}=0.62\right)$ and the slope of the relationship became positive with increasing $\mathrm{VEG}_{\mathrm{H}}$ correlated to increasing $\mathrm{Con}_{\text {yield. }}$ The $\% \mathrm{SS}_{\mathrm{UAA}}>5000 \mathrm{~m}^{2}$ was a significant univariate predictor of variability in catchment Con $_{\text {yield }}$ across all flow states (Figure 9c). During the annual, wet, and transition periods, the relationship was negative and weaker $\left(r^{2}=0.54\right.$ and 0.61 , respectively, with $\left.p<0.05\right)$ and increasing $\mathrm{SS}_{\mathrm{UAA}}>5000 \mathrm{~m}^{2}$ resulted in lower Con $_{\text {yield }}$ across catchments. This relationship shifted direction and became stronger $\left(r^{2}=0.80, p<0.05\right)$ during the dry period, where increasing $\% \mathrm{SS}_{\mathrm{UAA}>5000 \mathrm{~m}^{2}}$ resulted in larger $\mathrm{Con}_{\text {yield }}$.

[30] Table 4 lists the combinations of significant predictors of $\mathrm{Con}_{\text {yield }}$ in multiple regression models during the annual, wet, transition, and dry time periods. Full water year (annual) differences in $\mathrm{Con}_{\text {yield }}$ across all 11 catchments were explained by the combination of DFC/GTC and $\mathrm{VEG}_{\mathrm{H}}$ (Figures 10a and 10b). Eighty-five percent of the variance during the annual period was explained by $\mathrm{DFC} /$ GTC alone. This increased to $91 \%$ with the addition of $\mathrm{VEG}_{\mathrm{H}}$. DFC/GTC alone explained most of the variability in $\mathrm{Con}_{\text {yield }}$ (Figures 10a and 10b) during the wet $\left(r^{2}=\right.$ $0.79)$ and transition periods $\left(r^{2}=0.91\right) . \% \mathrm{SS}_{\mathrm{UAA}}>5000 \mathrm{~m}^{2}$ was the only significant predictor $\left(r^{2}=0.81\right)$ of catchment $\mathrm{Con}_{\text {yield }}$ during the dry period (Figures $10 \mathrm{a}$ and $10 \mathrm{~b}$ ).

\section{Discussion}

\subsection{How Does HRS Connectivity Relate to Runoff Observed at Each Catchment Outlet?}

[31] Our results indicated that landscape structure, specifically the topography of hillslopes entering the stream network, imparts a strong signature to the spatial pattern and timing of HRS shallow groundwater connectivity. The sequencing of stream network connectivity across space and time was a first-order control on runoff observed at each catchment's outlet. We documented this across 11 catchments and further partitioned the annual relationship between connectivity and runoff into three hydrologic regimes, and examined the factors that affect the strength and slope of these relationships.

[32] The amount of each catchment's stream network hydrologically connected to its uplands varied through time according to catchment wetness conditions (Figure 3). However, there was significant intracatchment variability in the spatial extent of stream network connectedness over annual and seasonal time periods (Figure 10a). Across the 11 TCEF catchments, stream network connectivity ranged from $56 \%$ to $80 \%$ during the wettest snowmelt conditions and decreased to $1 \%-10 \%$ during summer and winter base flow periods (Figure 4). These differences can be attributed to how the hillslope area was accumulated along the stream network within each of the catchments. Catchments (e.g., SPC) with more dissected topography (greater hillslope convergence and divergence) overall, had a higher frequency of 
Stream Network Connectivity (\%)

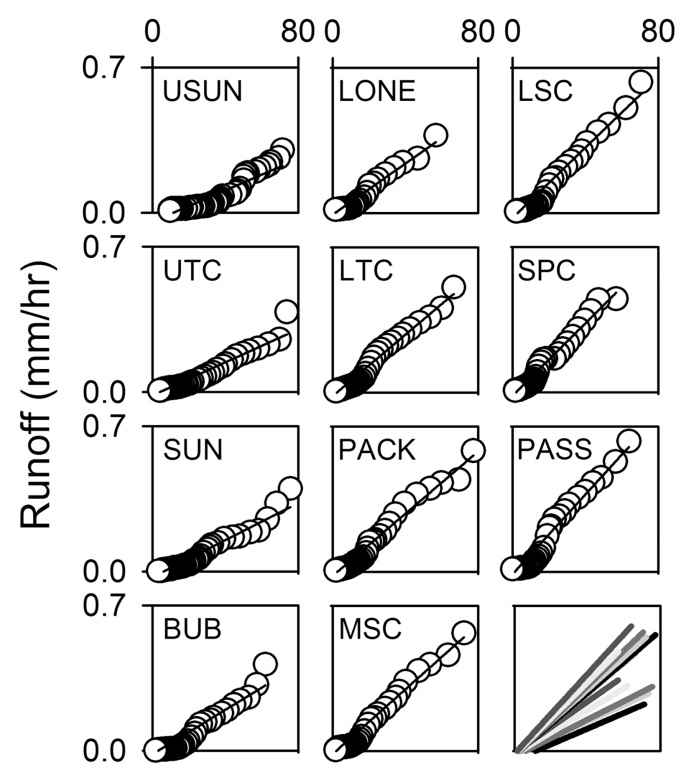

Figure 5. Linear fit to the relationship between the percentage of the stream network connected (CDC) and runoff magnitude (FDC) for the 2007 water year $(0 \%-100 \%$ exceedance). The bottom right plot depicts all of the linear fits to highlight annual variability in $\mathrm{Con}_{\text {yield }}$ across the TCEF catchments. The correlations for each model fit are included in Table 2.

\section{Stream Network Connectivity (\%)}

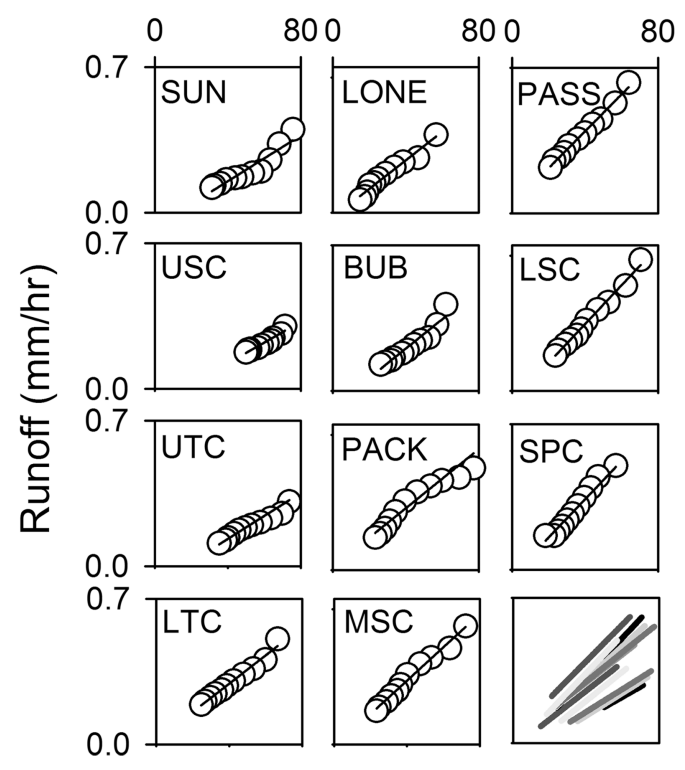

Figure 6. Linear fit to the relationship between the percentage of the stream network connected (CDC) and runoff magnitude (FDC) during the wettest catchment states $(0 \%-$ $10 \%$ exceedance). The bottom right plot depicts all of the linear fits to highlight variability in $\mathrm{Con}_{\text {yield }}$ during peak flow across the TCEF catchments. The correlations for each model fit are included in Table 2.

\section{Stream Network Connectivity (\%)}

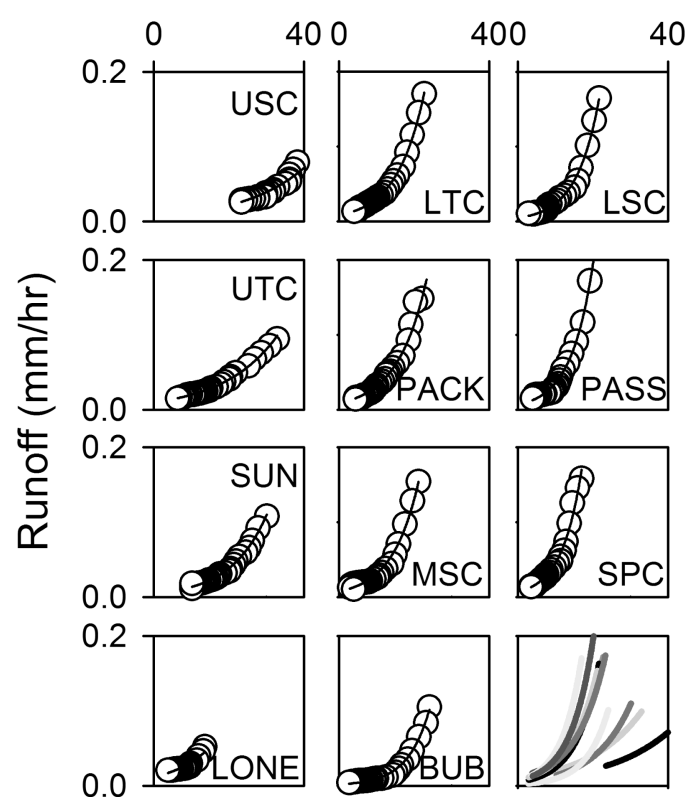

Figure 7. Exponential fit to the relationship between the percentage of the stream network connected (CDC) and runoff magnitude (FDC) during the transition from wet to dry states $(10 \%-50 \%$ exceedance). The bottom right plot depicts all of the exponential fits to highlight variability in

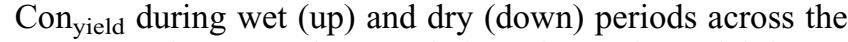
TCEF catchments. The correlations for each model fit are included in Table 2.

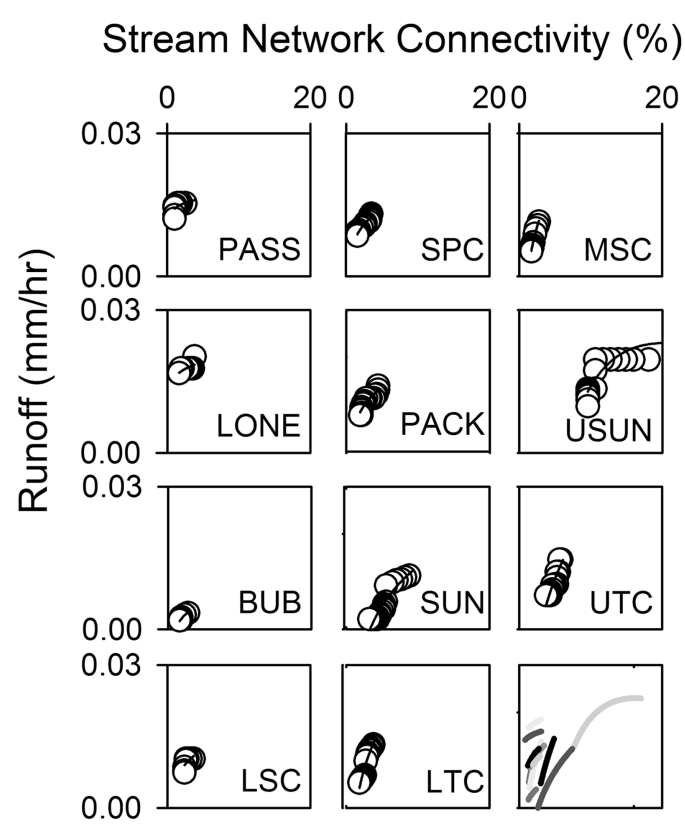

Figure 8. Logarithmic fit to the relationship between the percentage of the stream network connected (CDC) and runoff magnitude (FDC) during the driest catchment states (50\%-100\% exceedance). The bottom right plot depicts all of the log fits to highlight variability in Con yield $_{\text {across the }}$ TCEF catchments during low flow conditions. The correlations for each model fit are included in Table 2. 
Table 2. Median Values of Retained Landscape Predictor Variables and Con yield for the Annual, Wet, Transition, and Dry Time Periods $^{\mathrm{a}}$

\begin{tabular}{|c|c|c|c|c|c|c|c|}
\hline Catchment & $\mathrm{DFC} / \mathrm{GTC}$ & $\mathrm{VEG}_{\mathrm{H}}$ & $\% \mathrm{SS}_{\mathrm{UAA}>5000 \mathrm{~m}^{2}}$ & Annual Con $_{\text {yield }}$ & Wet Con $_{\text {yield }}$ & Transition Con $_{\text {yield }}$ & Dry Con ${ }_{\text {yield }}$ \\
\hline \multirow[t]{2}{*}{ SPC } & 3098 & 4.85 & 13 & 0.0087 & 0.0092 & 0.184 & 0.0045 \\
\hline & & & & 0.98 & 0.98 & 0.99 & 0.89 \\
\hline \multirow[t]{2}{*}{ LSC } & 3139 & 4.80 & 16 & 0.0085 & 0.0093 & 0.155 & 0.0042 \\
\hline & & & & 0.97 & 0.98 & 0.98 & 0.47 \\
\hline \multirow[t]{2}{*}{ LTC } & 4443 & 5.04 & 19 & 0.0074 & 0.0068 & 0.133 & 0.0128 \\
\hline & & & & 0.98 & 0.98 & 0.99 & 0.93 \\
\hline \multirow[t]{2}{*}{ MSC } & 3865 & 4.97 & 19 & 0.0078 & 0.0080 & 0.139 & 0.0133 \\
\hline & & & & 0.98 & 0.98 & 0.93 & 0.98 \\
\hline \multirow[t]{2}{*}{ UTC } & 10,727 & 5.52 & 27 & 0.0039 & 0.0055 & 0.071 & 0.0192 \\
\hline & & & & 0.95 & 0.87 & 0.99 & 0.91 \\
\hline \multirow[t]{2}{*}{ SUN } & 7892 & 5.20 & 20 & 0.0044 & 0.0055 & 0.103 & 0.0115 \\
\hline & & & & 0.94 & 0.88 & 0.98 & 0.88 \\
\hline \multirow[t]{2}{*}{ BUB } & 5000 & 5.20 & 17 & 0.0053 & 0.0071 & 0.140 & 0.0036 \\
\hline & & & & 0.93 & 0.92 & 0.97 & 0.93 \\
\hline \multirow[t]{2}{*}{ USC } & 10,454 & 5.36 & 22 & 0.0037 & 0.0050 & 0.060 & 0.0144 \\
\hline & & & & 0.86 & 0.93 & 0.97 & 0.78 \\
\hline \multirow[t]{2}{*}{ LONE } & 7114 & 4.91 & 14 & 0.0062 & 0.0069 & 0.116 & 0.0022 \\
\hline & & & & 0.95 & 0.97 & 0.69 & 0.34 \\
\hline \multirow[t]{2}{*}{ PACK } & 4358 & 4.89 & 16 & 0.0075 & 0.0071 & 0.136 & 0.0055 \\
\hline & & & & 0.97 & 0.95 & 0.99 & 0.89 \\
\hline \multirow[t]{2}{*}{ PASS } & 2516 & 4.62 & 14 & 0.0096 & 0.0089 & 0.180 & 0.0008 \\
\hline & & & & 0.95 & 0.99 & 0.90 & 0.88 \\
\hline
\end{tabular}

${ }^{\mathrm{a}} \mathrm{Con}_{\text {yield }}$ was estimated based on the linear (annual and peak), exponential (transition), and logarithmic (dry) fits to the relationship between stream network connectivity and runoff magnitude at $1 \%$ increments. The slope for each of these relationships is indicated in bold along with the correlation val ue. Predictor variables were input into linear regression models to explain the differences in Con ${ }_{\text {yield }}$ across catchments and time periods.

smaller hillslope area inputs and lower median local inflows of UAA to the stream network. This resulted in a higher proportion of short duration HRS connectivity along the stream network and less HRS connectivity during peak snowmelt ( $\sim 56 \%$ network connectivity in SPC; Figure 3$)$. Less-dissected catchments (e.g., PACK) had higher median UAA values, elevated annual connectivity, and higher maximum HRS network connectivity ( $\sim 80 \%$ network connectivity).

[33] Each stream network CDC was strongly correlated to its respective FDC for all 11 catchments across the annual, peak, transition, and base flow time periods (Table 2). While it is not surprising that they are positively correlated, the degree of correlation suggests process linkages that are intuitive, yet not previously observed or quantified. The shape of the FDC appears to be largely controlled by the fraction of the stream network hydrologically connected to the uplands throughout the year. During the driest fall and winter base flow periods ( $50 \%$ of the year), the lowest runoff ranging from 0.016 to $0.002 \mathrm{~mm} \mathrm{~h}^{-1}$ corresponded to between $1 \%$ and $10 \%$ of each catchments stream network connected to its uplands. Breaks in slope (inflection points) of the stream FDCs at between 0.21 and $0.05 \mathrm{~mm} \mathrm{~h}^{-1}$ corresponded to a parallel increase in network connectivity (Figures 3 and 4). These synchronous inflection points temporally map to the first snowmelt and early summer

Table 3. Correlation Coefficients for the Significant Topographic, Vegetation, and Geology Predictors

\begin{tabular}{lccc} 
& UAA $\left(\mathrm{m}^{2}\right)$ & $\% \mathrm{SS}_{\mathrm{UAA}>5000 \mathrm{~m}^{2}}$ & $\mathrm{VEG}_{\mathrm{H}}$ \\
\hline $\mathrm{DFC} / \mathrm{GTC}$ & 0.71 & 0.78 & 0.88 \\
$\mathrm{VEG}_{\mathrm{H}}$ & 0.67 & 0.89 & \\
$\mathrm{oSS}_{\mathrm{UAA}>5000 \mathrm{~m}^{2}}$ & 0.66 & & \\
\hline
\end{tabular}

dry-down which comprise the transition period between wet and dry catchment states. During the wettest catchment states (snowmelt and the largest rain events), hillslopes possessing smaller UAA became connected to the stream network. The cumulative connections of small UAA, in addition to previously connected medium and large UAAs, led to greater stream network connectivity and subsequently larger magnitude runoff (Figure 10a). During the largest events ( $\sim 10 \%$ of the year) between $56 \%$ to $80 \%$ of each catchments stream network was hydrologically connected to its uplands. This resulted in peak runoff ranging from $0.31-0.63 \mathrm{~mm} \mathrm{~h}^{-1}$ across catchments. These CDC:FDC relationships suggest that the magnitude and timing of runoff response across catchments was largely a function of the topographically controlled hydrologic connectivity frequency and duration.

[34] Those catchments with generally higher and more sustained connectivity also exhibited the greatest divergence between the CDC and FDC across time (Figure 3). Catchments where these relationships diverged could be indicative of other variables impacting the relationship between topography and runoff. For example, the catchments with relatively high stream network connectivity relative to runoff could be affected by greater evapotranspiration (e.g., aspect or vegetation differences) or differences in geology, or slope. This suggests potential hierarchical influences for stream network HRS connectivity and runoff magnitude through time. How these interactions might combine to influence runoff generation is discussed in section 5.2.

\subsection{What Factors Contribute to Differences in the Connectivity Yield Observed Across the 11 Catchments?}

[35] The CDC-FDC regression model fits were significant across all catchments, yet each exhibited a different 


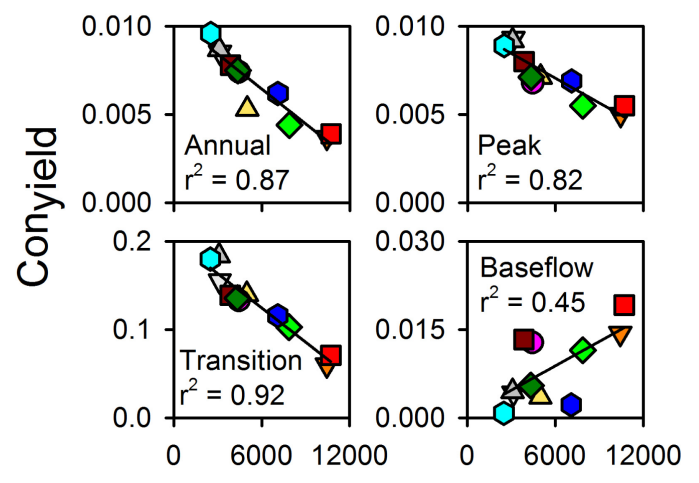

(a) Median DFC/GTC

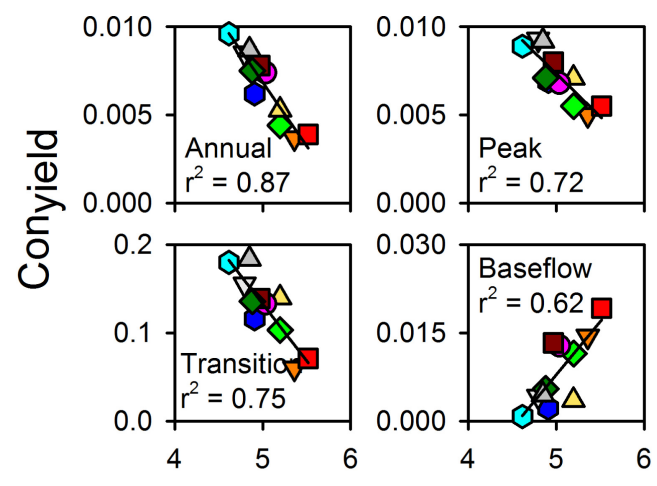

(b) Median Tree Height ( $m$ )

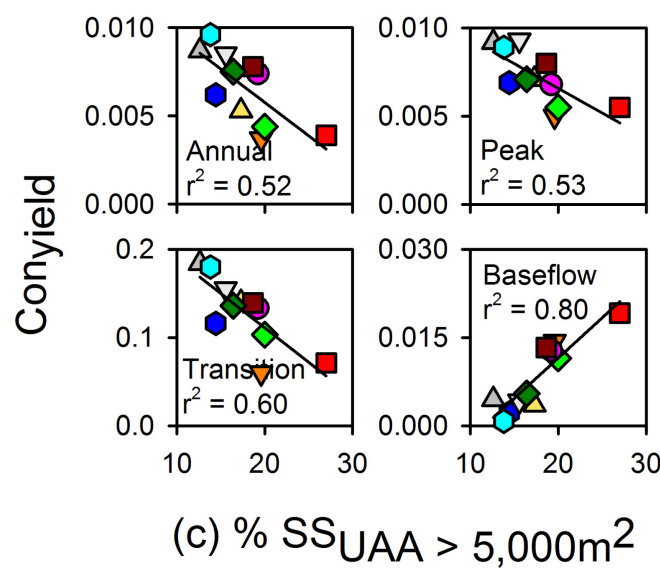

Figure 9. Linear relationships between the $\mathrm{Con}_{\text {yield }}$ for 11 TCEF catchments during the annual, wet, transition, and dry periods and median values of the (a) DFC/GTC, (b) tree height, and (c) percentage of catchment sandstone overlain by UAA $>5000 \mathrm{~m}^{2}$. The symbol colors designate the TCEF subcatchments and are the same as those shown in Figure 4. The combinations of these predictors explain variability in catchment $\mathrm{Con}_{\text {yield }}$ across flow states within multiple linear models (Table 2).

slope or rate of change of runoff with respect to stream network connectedness $\left(\mathrm{Con}_{\text {yield }}\right.$; Figure 5). This suggested other factors that might influence Con $_{\text {yield }}$ and the shape of the CDC and FDC across flow states. The results from our linear models suggest that in addition to the first-order UAA variable, flow path lengths and gradients and their ratios (DFC/GTC), vegetation structure, and surface geology explain differences in $\mathrm{Con}_{\text {yield }}$ across the 11 catchments (Figures 10a and 10b). In sections 5.2.1-5.2.3 we describe each of these predictor variables and how we interpret their influence on HRS connectivity-induced runoff generation through space and time.

\subsubsection{DFC/GTC}

[36] The frequency distribution of flow path lengths divided by the gradient along each flow path (DFC/GTC ratios) can be considered a catchment-scale approximation of the hydraulic force driving water redistribution (i.e., Darcy's law) [McGlynn and Seibert, 2003; Seibert and McGlynn, 2003; McGuire et al., 2005; Gardner and McGlynn, 2009] in the shallow subsurface. While the stream network distributions of UAA largely determine the extent of stream network connectedness (Table 2), our analyses suggest that the combination of flow path lengths and gradients is important for describing the rate of water redistribution through different UAAs and to the stream.

[37] The relationships between the median DFC/GTC ratios and connectivity yield ( $\left.\mathrm{Con}_{\text {yield }}\right)$ differed across catchments. The catchments with the lowest DFC/GTC ratios exhibited the highest $\mathrm{Con}_{\text {yield }}$ (Figure 9) except at base flow. This means that in steeper and/or more highly dissected catchments with shorter flow paths, more streamflow was generated per unit stream network connectivity than in other catchments. In less complex catchments with longer flow paths and/or gentler slopes, decreasing DFC/ GTC ratios were correlated to decreased Con yield $_{\text {(Figure 9). }}$. This suggests that the inclusion of metrics such as DFC/ GTC that describe the velocity and relative time of concentration of water from the uplands to the stream may be more important for a priori estimates of the streamflow magnitude associated with a given stream network connectivity fraction.

[38] In the multiple linear analyses, DFC/GTC was a significant predictor during the wet and transition periods, and when combined with $\mathrm{VEG}_{\mathrm{H}}$ was significant at the annual timescale (Table 4; Figures 10a and 10b). These results are relatively intuitive since the initiation of lateral flow, and therefore topographic controls, depend largely on saturated soil conditions attributed to wetter catchment periods [Western et al., 1999]. The strength of the univariate relationship between DFC/GTC and Con $_{\text {yield }}$ (Figure 9) decreased from the wet and transition time periods $\left(r^{2}=\right.$ 0.82 and 0.92 , respectively) to the base flow time period $\left(r^{2}=0.45\right)$. This shift was likely because of the depletion of upslope soil moisture storage due to lateral water redistribution and a switching from saturated to unsaturated soil conditions. This resulted in a transition from topographi-

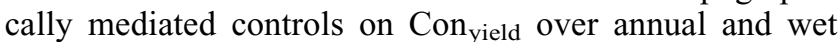
time periods to an increasing influence of factors such as vegetation and geology during drier times.

\subsubsection{Vegetation}

[39] Forest cover can affect snow accumulation [Woods et al., 2006], the energy balance and snowmelt timing [Pomeroy et al., 1998; Baldocchi et al., 2000], landscape transpiration patterns [Kelliher et al., 1993], rainfall interception, and evaporation [Gerrits et al., 2010], and can 
Table 4. Multiple Linear Models for Con $_{\text {yield }}$ Listed in Order of Decreasing Streamflow ${ }^{\mathrm{a}}$

\begin{tabular}{lccccc}
\hline Flow Period & Adjusted Multiple $r^{2}$ & Intercept & DFC/GTC & Tree Height & Sandstone $_{\text {UAA }>5000 \mathrm{~m}^{2}}(\%)$ \\
\hline Annual & 0.91 & 0.028 & $-3.5 \mathrm{E}-07$ & -0.004 & - \\
Linear fit & & $<\mathbf{0 . 0 1}$ & $\mathbf{0 . 0 3}$ & $\mathbf{0 . 0 4}$ & - \\
Wet & 0.79 & 0.010 & $-4.7 \mathrm{E}-07$ & - & - \\
Linear fit & & $<\mathbf{0 . 0 1}$ & $<\mathbf{0 . 0 1}$ & - \\
Transition & 0.91 & 0.20 & $-1.3 \mathrm{E}-05$ & - \\
Exp fit & & $<\mathbf{0 . 0 1}$ & $\mathbf{0 . 0 1}$ & - & 0.001 \\
Dry & 0.81 & $\mathbf{0 . 0 1 6}$ & - & $\mathbf{< . 0 1}$ \\
Log fit & & $\mathbf{0 . 0 1}$ & & & - \\
\hline
\end{tabular}

${ }^{\text {a }}$ Regression coefficients are listed with their associated $p$-value (bold). A missing value indicates that the predictor was not retained in the final model. Variables that were not found to be significant during any of the flow states were omitted.

therefore be an important sink for water in the shallow subsurface [Albertson and Kiely, 2001]. Forested catchments in strongly seasonal climates exhibit large variations in their rates of transpiration. In semiarid catchments such as the TCEF, up to $65 \%$ of annual precipitation can be transpired back to the atmosphere. Therefore, differences in transpiration and associated soil moisture deficits could impact the water available for streamflow and thus the slope of the relationship between a catchment's CDC and FDC ( Con $\left._{\text {yield }}\right)$.

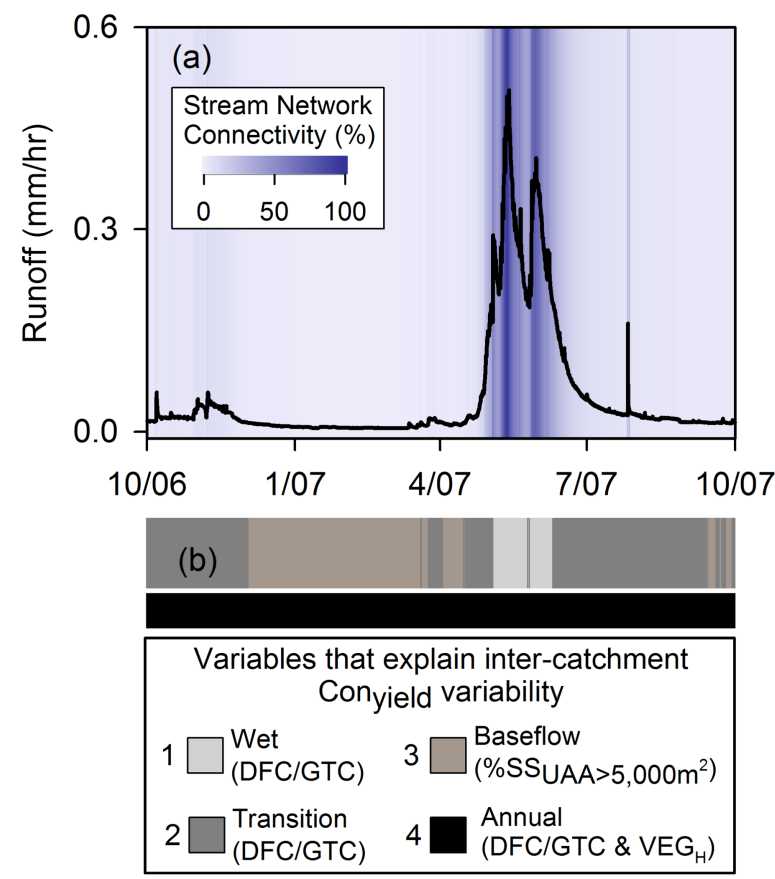

Figure 10. Time series illustrating the hierarchical con-

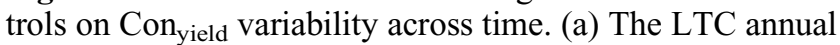
hydrograph and modeled stream network connectivity. (b) Variance in $\mathrm{Con}_{\text {yield }}$ across catchments was explained by topography, vegetation, and geology predictors within multiple linear models $(1-4)$ for different flow states. Con yield $_{\text {- }}$ variability during wet (1) and transitional (2) time periods was described by the DFC/GTC $\left(r^{2}=0.79\right.$ and 0.91 , respectively). During base flow (3) the percentage of sandstone overlain by UAA $>5000 \mathrm{~m}^{2}$ was the only significant predictor of Con $_{\text {yield variability }}\left(r^{2}=0.81\right)$. DFC/GTC and vegetation height (4) were significant predictors at the annual time scale $\left(r^{2}=0.91\right)$.
[40] Univariate relationships indicated that median catchment $\mathrm{VEG}_{\mathrm{H}}$ was a significant predictor of $\mathrm{Con}_{\text {yield }}$ across catchments over annual, wet, and transition periods. Larger tree heights were well correlated to a reduction in streamflow for a given amount of stream network connectivity (Figure 9). At the annual, transition, and base flow time periods this reduction in flow would be associated with greater leaf area index (LAI) and potentially greater rates and duration of transpiration of available soil water from taller trees [Komatsu, 2005]. Additionally, higher leaf area and taller trees can increase mechanical turbulence (through variability in surface roughness) and canopy conductance, both leading to higher rates of evapotranspiration. During the wetter snowmelt periods, reductions in $\mathrm{Con}_{\text {yield }}$ could be attributed to forest cover and leaf area effects on snow accumulation [Woods et al., 2006; Rinehart et al., 2008], redistribution [Hiemstra et al., 2002], and melt due to canopy effects on the local energy balance [Varhola et al., 2010; Rinehart et al., 2008]. It is also possible that a legacy of soil moisture deficit from the previous growing season could persist in forested areas with mature, taller trees thereby affecting Con $_{\text {yield }}$ in subsequent seasons. This may have resulted in a larger storage deficit to be overcome for the initiation of lateral water redistribution and connectivity initiation during snowmelt. All of these factors could reduce the magnitude of water delivery to the stream network from hydrologically connected hillslope positions.

[41] Multiple linear models indicated that $\mathrm{VEG}_{\mathrm{H}}$ was only a significant predictor of $\mathrm{Con}_{\text {yield }}$ at the annual timescale in combination with DFC/GTC (Table 4; Figures 10a and $10 \mathrm{~b}$ ). While vegetation is likely to be most influential during the transitional period (growing season) in semiarid climates such as the TCEF, our analysis was not able detect vegetative effects on lateral water redistribution during subannual time periods. However, given adequate time integration, these catchment-scale relationships do suggest vegetative control on the partitioning and redistribution of water through the shallow subsurface that influences Conyield. Further landscape-scale investigations are needed to evaluate the interplay between patterns of vegetation water-use efficiency, hydrologic connectivity, and runoff generation across finer space and timescales.

5.2.3. Intersection of Surface Topography and Geology

[42] The comparison of $\mathrm{Con}_{\text {yield }}$ and catchment geology suggested that surficial bedrock geology influences shallow subsurface water table dynamics. Many studies have investigated the variability in runoff response among catchments with different underlying bedrock [Freeze, 1972; Godsey 
et al., 2004; Onda et al., 2006], and bedrock controls on runoff generation have been observed at the hillslope [Hewlett and Hibbert, 1967; Montgomery et al., 1997; Onda et al., 2001; Tromp-van Meerveld et al., 2007; Iwagami et al., 2010] and catchment scales [Genereux et al., 1993; Tague and Grant, 2004]. Despite an acknowledgment of the potential for exchange between soil zone water tables, the underlying shallow subsurface bedrock, and deeper bedrock aquifers, few catchment hydrology studies have characterized the potential spatial variability of these interactions. We suggest that these interactions can influence hydrologic connectivity across catchments of complex structure, especially during low flow conditions.

[43] Univariate relationships between Con $_{\text {yield }}$ and the $\% \mathrm{SS}_{\mathrm{UAA}}>5000 \mathrm{~m}^{2}$ highlight the potential intersection of shallow groundwater connectivity with deeper bedrock flow systems. Catchments with a higher proportion of large UAA sizes $\left(>5000 \mathrm{~m}^{2}\right)$ intersecting the sandstone strata exhibited lower runoff per unit of stream network connectivity (negative relationship) during annual, peak, and transitional periods (Figure 9). However, during the lowest flow periods the slope of this relationship shifted direction, becoming positive and stronger $\left(r^{2}=0.80, p<0.05\right.$, Table 2$)$. $\% \mathrm{SS}_{\mathrm{UAA}}>5000 \mathrm{~m}^{2}$ was the only significant predictor of $\mathrm{Con}_{\text {yield }}$ during the driest catchment conditions in our multiple linear analyses, suggesting a shifting affect of geology on $\mathrm{Con}_{\text {yield }}$ and its dominance during low flows (Table 2; Figures 10a and 10b). During wetter periods in persistently connected hillslope positions (large UAA $>5000 \mathrm{~m}^{2}$ ), water in the shallow subsurface moves laterally to the stream network as a function of UAA and the DFC/GTC but also infiltrates into the more permeable sandstone surficial geology. The bedrock aquifer contributions to the stream are small relative to the amount of water moving through the soil profile in connected hillslope positions. During low base flow and times of low stream network connectivity (Figures 10a and 10b), the sandstone becomes a more significant source of streamflow. Water that infiltrated into the sandstone during wetter times would be slowly released to the stream network, leading to a higher runoff magnitude and differences in $\mathrm{Con}_{\text {yield }}$ during low flow conditions. The degree to which this recharge-discharge or sink-source status occurs across catchments is likely a function of the intersection of surficial geologic strata permeability/storage characteristics with hydrologically connected hillslope positions.

[44] Water recharging the stream from the sandstone could enter the stream network at locations not predicted by surface topography (e.g., UAA and DTC/GTC metrics) alone. Larger-scale hydraulic gradients may drive deep groundwater flow paths, independent of smaller-scale surface topography, which could influence the location of base flow runoff generation [Tóth, 1963]. In addition, water infiltrating the sandstone strata from overlying soil zones along hydrologically connected hillslopes might be less likely to follow surface topography due to bedrock dip, stratigraphy, and possible fractures. Payn et al. [2011] suggested that there could be a shift from topographic to bedrock controls on the spatial patterns of stream base flow across three TCEF subcatchments from wet to dry watershed conditions. The influence of bedrock during base flow was evident in data from intensive streamflow measurements every $200 \mathrm{~m}$ across LTC,
LSC, and SPC stream networks. Increases in specific discharge (area normalized runoff) were generally and consistently lower in stream reaches underlain by sandstone. However, low upstream yields were compensated by high downstream yields near reaches of the sandstone to granite gneiss contact. These observations collectively support the premise that water from hydrologically connected hillslope positions infiltrates the surficial sandstone bedrock strata during wet times and re-emerges to contribute to streamflow lower in the catchment during drier time periods. This leads to a shift of the slope of the $\mathrm{Con}_{\text {yield }}$-sandstone relationship across wet to dry time periods (Figure 9, Table 2).

\subsubsection{Correlation Between Factors Affecting Catchment Con yield $_{\text {. }}$}

[45] The correlation among retained landscape metrics may partially explain the lack of multiple predictor variables of Con $_{\text {yield }}$ during subannual time periods. Our analysis indicated correlation among metrics of topography, vegetation, and geology that led to differences in catchment Con $_{\text {yield }}$ (Table 3). This is not surprising given the coevolution of landscape variables, partially mediated by, and then affecting, the movement of water through catchments. Topography often emerges from feedbacks between different geomorphic processes under the influence of catchment properties such as surficial geology, soils, and vegetation. Each of these properties vary naturally in space and longer timescales, leading to differential erosion rates within catchments, and therefore differences in observed landscape morphology [Leopold and Langbein, 1962; Leopold et al., 1964; Schmidt and Montgomery, 1995; Dietrich and Perron, 2006; Yetemen et al., 2010]. This may be the case in the TCEF where feedbacks between catchment geology, vegetation, and topography led to differences in landscape morphology and subsequent variability in the slope of the $\mathrm{Con}_{\text {yield }}$ relationship across space and time.

\subsection{Implications}

[46] A persistent question in catchment hydrology is which factors affect catchment response most strongly [Hewlett and Hibbert, 1967]? We observed variability between the degree of stream network connectivity and catchment discharge across nested and seemingly similar catchments. Important characteristics contributing to this variability included metrics of surface topography, vegetation, and geology. Between $91 \%$ and $80 \%$ of the variance in $\mathrm{Con}_{\text {yield }}$ was explained by the intersection of these predictor variables in the multiple linear models across annual and seasonal time periods (Figure 10). These relationships provide insight and potential hypothesis testing frameworks to further examine the relative influence of topography, vegetation, and geology for mediating hydrological connectivity, water redistribution/storage, and runoff dynamics across different catchments. These factors may also explain variance in the landscape UAA-HRS connectivity relationship (Figure 2), and could be highly influential on upslope water balances and thresholds of connectivity initiation and cessation observed across different hillslope contributing areas. Future work that aims to physically quantify the influence of these and other factors on shallow subsurface response within catchments is crucial to de-convoluting their relative influence on runoff dynamics observed at the catchment outlet. 
[47] Up to $19 \%$ of the variance in $\mathrm{Con}_{\text {yield }}$ could not be explained by multiple regression models for the annual and seasonal time periods. This suggests that there are secondary controls on water redistribution and runoff generation across the 11 TCEF catchments. Two potentially important hydrologic variables not represented in these analyses include distributions of soil depth/textural properties and the spatial variability of precipitation and snowmelt. Soil depths to bedrock in the TCEF are $\sim 1 \mathrm{~m}$ and have been found to be relatively homogenous across the landscape ( $\sim 300$ depth measurements and soil pits). However, even slight differences in soil depth or soil characteristics such as texture and macroporosity associated with different soil types could influence water holding capacity [Hewlett and Hibbert, 1967], unsaturated/saturated hydraulic conductivities, the switching between vertical and lateral water redistribution [Western et al., 1999], and therefore shallow subsurface runoff magnitude across different UAAs. These nonlinearities would also be enhanced by the timing and magnitude of precipitation across the landscape. Current climate forcing in conjunction with antecedent soil moisture conditions attributed to past forcing could also influence the partitioning of event water to the shallow subsurface [Tromp-van Meerveld and McDonnell, 2006] or to deeper groundwater flow pathways [Iwagami et al., 2010]. These additional variables and a myriad of other heterogeneities could lead to the unexplained variance in catchment $\mathrm{Con}_{\text {yield }}$ through time.

[48] There are many characteristics of a catchment that can affect how water is redistributed across space and time. We have identified the factors that have the strongest influence on water redistribution and runoff generation in 11 nested semiarid mountainous catchments (Figure 11). How these or additional variables integrate to produce whole catchment behavior in other environments or across interbasin scales requires further attention. Field-based investigations have been conducted across a wide array of research catchments and have identified numerous controls on runoff generation, including climate [Arnell, 1996; Barnett et al., 2005], topography [Anderson and Burt, 1978; Beven, 1978; McGuire et al., 2005], soil distributions [Buttle et al., 2004; Soulsby et al., 2004, 2006], geology [Huff et al., 1982; Genereux et al., 1993; Wolock et al., 1997; Burns et al., 1998; Tague and Grant, 2004; Onda et al., 2001, 2006], and vegetation [Hewlett and Hibbert, 1967; Emanuel et al., 2010]. The research presented here provides a framework for addressing this problem and suggests that the relative influence of a particular set of factors will vary according to the intersection of their spatial patterns (Figure 11) and relevant hydrologic properties within a particular catchment. The importance of each shifts across time with changing climate and antecedent storage conditions.

[49] Consideration of the spatial patterns of hydrologic variables is also important for assessing how disturbance patterns and climate variability will affect catchment water quantity and quality. Climate variability has the potential to interact with land cover change and alter and increase the impacts of natural and anthropogenic disturbance patterns in the landscape [Vose et al., 2011], and may therefore impact the amount and quantity of water traveling along shallow and deeper groundwater flow pathways. For example, mild winters and drought in Northwest America have resulted in increased tree mortality due to mountain pine

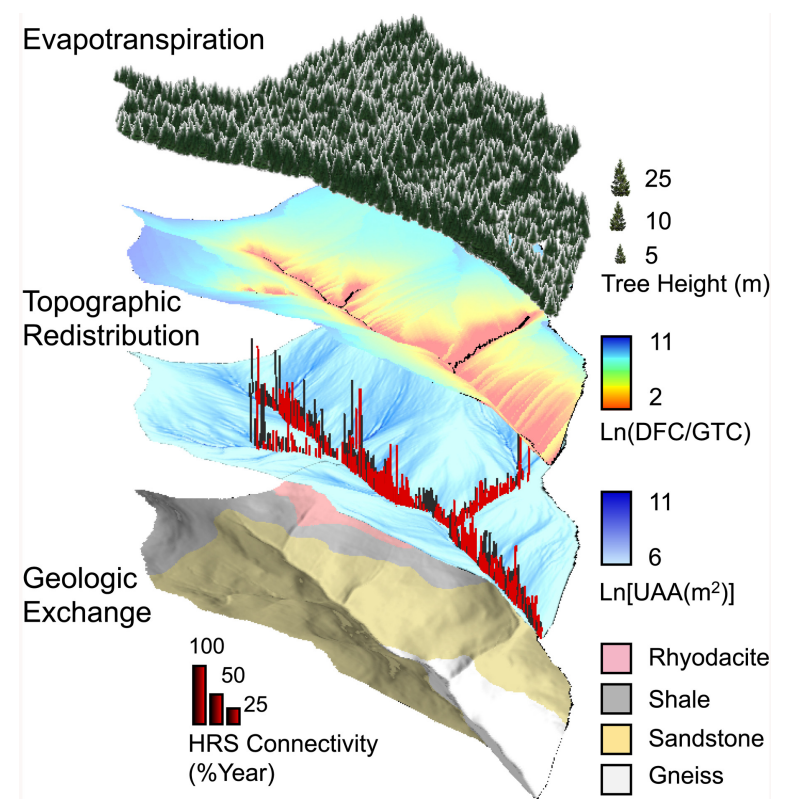

Figure 11. A conceptual diagram illustrating the hierarchical controls on runoff generation across the 11 TCEF catchments. Combinations of median tree height, DFC/ GTC, and sandstone overlain by UAA $>5000 \mathrm{~m}^{2}$ explained a significant amount of the variability in catchment $\mathrm{Con}_{\text {yield }}$ across the flow states. DFC/GTC and vegetation height were significant predictors at the annual timescale. $\mathrm{Con}_{\text {yield }}$ variability during wet and transitional time periods was described by the DFC/GTC. During base flow the percentage of sandstone overlain by UAA $>5000 \mathrm{~m}^{2}$ was the only significant predictor of $\mathrm{Con}_{\text {yield }}$ variability.

beetle outbreaks [Ayres and Lombardero, 2000], and warming is modifying snowmelt regimes [Mote et al., 2005; Pederson et al., 2009] and the frequency and magnitude of large wildfires [Gillete et al., 2004; Westerling et al., 2006; Littell et al., 2009]. To understand how these patterns of disturbance and climate change might influence water yield across diverse catchments it is necessary to consider the intersection of their spatial patterns with mediating hydrologic variables such as topography, vegetation, and geology. Where these disturbance patterns occur within a landscape may lead to a differential manifestation of their influence at the catchment outlet. Additionally, hillslope-scale studies that address both shallow subsurface and deeper groundwater flow components are needed to assess the impact of local disturbance in a larger watershed context.

\section{Conclusion}

[50] Multiple catchment- and distributed landscape-scale observations in TCEF support the concept of hierarchical controls on streamflow with their relative influence varying across different time periods. Strong relationships between runoff and topographically derived hydrologic connectivity estimates indicate that streamflow from the 11 TCEF catchments is dominantly topographically driven. Variability in the slope of the relationship between topographically scaled hydrological connectivity observations and stream discharge 
led to the analysis of additional explanatory variables that varied in their explanatory power across annual and seasonal timescales. These variables included the distributions of flow path lengths and gradients, vegetation, and geology indices. Our results and analyses provide insight into the combinations of catchment characteristics such as topography, vegetation, and geology that can affect hydrological connectivity, water redistribution/storage, and resultant runoff dynamics. On the basis of our analysis we conclude:

[51] 1. Stream network hydrologic connectivity is the first-order control on runoff magnitude observed at catchment outlets.

[52] 2. Stream network connectivity yield $\left(\mathrm{Con}_{\text {yield }}\right)$ was a function of the interaction between topographically mediated hydrologic connectivity and metrics that act to reduce or enhance water redistribution across connected landscape positions.

[53] a. Increasing flow path length to gradient ratios were correlated with decreased Con yield; $_{\text {; }}$

[54] b. Taller vegetation was correlated with decreased Con $_{\text {yield }}$ across catchments; and

[55] c. Increasing proportions of permeable geology underlying wetter landscape positions was correlated with decreased $\mathrm{Con}_{\text {yield }}$ in wetter time periods and enhanced Con $_{\text {yield }}$ in drier time periods.

[56] 3. The relative influence of topographic, vegetative, and geologic predictors changed through time according to catchment wetness states. The topography was most influential for water redistribution and connectivity dynamics during snowmelt and the annual dry down. Both vegetation and geology become more influential during drier base flow periods.

[57] Our results suggest that spatio-temporal distributions of hillslope-riparian-stream hydrologic connectivity across 11 diverse but adjacent catchments can provide insight into runoff source area dynamics, runoff implications of catchment morphology and topology, and a direct and quantifiable link between catchment structure, vegetation, geology, and hydrologic dynamics. These findings are an important consideration in the context of rainfall-runoff model development. Traditionally, complexity resulting from the addition of many parameters within rainfall-runoff models has led to increased uncertainty, decreased predictive power, and limited flexibility when attempting to model hydrology in catchments with limited a priori information. The conceptualizations of connectivity developed from this work represent simple, empirically based metrics for predicting runoff response. When incorporated within a modeling framework, these conceptualizations may prove to be useful tools for the prediction of runoff response across catchments of differing structure and for accurate representation of internal landscape hydrologic response dynamics.

[58] Acknowledgments. This work was made possible by NSF grant EAR-0337650 to B. L. McGlynn, and an Inland Northwest Research Alliance Fellowship awarded to K. G. Jencso. The authors appreciate extensive logistic collaboration with the USDA, Forest Service, Rocky Mountain Research Station, especially, Ward McCaughey, Scientist-in-Charge of the Tenderfoot Creek Experimental Forest for the period of this study. We thank Thomas Grabs, January Siebert, Lucy Marshall, Mike Gooseff, and Robert Payn for technical and collaborative support. We are grateful to Jennifer Jencso, Vince Pacific, Diego Riveros-Iregui, and especially Austin Allen for invaluable assistance in the field.

\section{References}

Albertson, J. D., and G. Kiely (2001), On the structure of soil moisture time series in the context of land surface models, J. Hydrol., 243(1-2), 101.

Ali, G. V., and A. G. Roy (2009), Revisiting hydrologic sampling strategies for an accurate assessment of hydrologic connectivity in humid temperate systems, Geography Compass, 3(1), 350-374.

Anderson, M. G., and T. P. Burt (1978), The role of topography in controlling throughflow generation, Earth Surf. Processes Landforms, 3, $331-334$.

Arnell, N. (1996), Global Warming, River Flows and Water Resources, 224 pp., Wiley, Chichester.

Ayres, M., and M. Lombardero (2000), Assessing the consequences of global change for forest disturbance from herbivores and pathogens, Sci. Total Environ., 262(3), 263-286.

Baldocchi, D., F. M. Kelliher, T. A. Black, and P. Jarvis (2000), Climate and vegetation controls on boreal zone energy exchange, Global Change Biol., 6, 69-83.

Barnett, T. P., J. C. Adam, and D. P. Lettenmaier (2005), Potential impacts of a warming climate on water availability in snow-dominated regions, Nature, 438(7066), 303-309.

Beven, K. J. (1978), The hydrological response of headwater and sideslope areas, Hydrol. Sci. Bulletin, 23, 419-437.

Böhner, J., T. Blaschke, and L. Montanarella (Eds.) (2008), SAGA: System for an Automated Geographical Analysis, 113 pp., Institute of Geography, Univ. Hamburg, Germany.

Bracken, L. J., and J. Croke (2007), The concept of hydrological connectivity and its contribution to understanding runoff-dominated geomorphic systems, Hydrol. Processes, 21(13), 1749-1763, doi:10.1002/hyp.6313.

Burns, D. A., P. S. Murdoch, G. B. Lawrence, and R. L. Michel (1998), Effect of groundwater springs on $\mathrm{NO}_{3}{ }^{-}$concentrations during summer in Catskill Mountain streams, Water Resour. Res., 34(8), 1987-1996, doi:10.1029/98WR01282.

Burt, T. P., and D. Butcher (1985), Topographic controls on soil moisture distribution, J. Soil Sci., 36, 469-476.

Buttle, J. M., P. J. Dillon, and G. R. Eerkes (2004), Hydrologic coupling of slopes, riparian zones and streams: An example from the Canadian Shield, J. Hydrol., 287(1-4), 161-177, doi:10.1016/j.jhydrol.2003.09. 022|ISSN 0022-1694.

Carlyle, G. C., and A. R. Hill (2001), Groundwater phosphate dynamics in a river riparian zone: Effects of hydrologic flowpaths, lithology, and redox chemistry, J. Hydrol., 247, 151-168.

Devito, K., I. Creed, T. Gan, C. Mendoza, R. Petrone, U. Silins, and B. Smerdon (2005), A framework for broad-scale classification of hydrologic response units on the Boreal Plain: Is topography the last thing to consider?, Hydrol. Processes, 19(8), 1705-1714, doi:10.1002/hyp.-5881.

Dietrich, W. E., and J. T. Perron (2006), The search for a topographic signature of life, Nature, 439(7075), 411-418.

Dubayah, R. O., and J. B. Drake (2000), Lidar remote sensing for forestry, J. Forestry, 98, 44-46.

Dunne, T., and R. D. Black (1970), Partial area contributions to storm runoff in a small New England watershed, Water Resour. Res., 6(5), 12961311, doi:10.1029/WR006i005p01296.

Emanuel, R. E., H. E. Epstein, B. L. McGlynn, D. L. Welsch, D. J. Muth, and P. D'Odorico (2010), Spatial and temporal controls on watershed ecohydrology in the northern Rocky Mountains, Water Resour. Res., 46, W11553, doi:10.1029/2009WR008890.

Farnes, P. E., R. C. Shearer, W. W. McCaughey, and K. J. Hansen (1995), Comparisons of Hydrology, Geology, and Physical Characteristics Between Tenderfoot Creek Experimental Forest (East Side) Montana, and Coram Experimental Forest (West Side) Montana, 19 pp., USDA Forest Service, Intermountain Research Station, Forestry Sciences Laboratory, Bozeman, MT

Freeze, A. R. (1972), Role of subsurface flow in generating surface runoff. 2. Upstream source areas, Water Resour. Res., 8(5), 1272-1283, doi:10.1029/WR008i005p01272.

Freeze, R. A., and J. A. Cherry (1979), Groundwater, 604 pp., PrenticeHall, Englewood Cliffs, N. J.

Gardner, K. K., and B. L. McGlynn (2009), Seasonality in spatial variability and influence of land use/land cover and watershed characteristics on stream water nitrate concentrations in a developing watershed in the Rocky Mountain West, Water Resour. Res., 45(8), W08411, doi:10.1029/2008WR007029.

Genereux, D. P., H. F. Hemond, and P. J. Mulholl (1993), Spatial and temporal variability in streamflow generation on the West Fork of Walker Branch Watershed, J. Hydrol., 142, 137-166. 
Gerrits, A. M. J., L. Pfister, and H. H. G. Savenije (2010), Spatial and temporal variability of canopy and forest floor interception in a beech forest, Hydrol. Processes, 24(21), 3011-3025.

Gillett, N. P., A. J. Weaver, F. W. Zwiers, and M. D. Flannigan (2004), Detecting the effect of climate change on Canadian forest fires, Geophys. Res. Lett., 31, L18211, doi:10.1029/2004GL020876.

Godsey, S., H. Elsenbeer, and R. F. Stallard (2004), Overland flow generation in two lithologically distinct rainforest catchments, J. Hydrol., 295, 276-290.

Grabs, T. J., K. G. Jencso, B. L. McGlynn, and J. Seibert (2010), Calculating terrain indices along streams: A new method for separating stream sides, Water Resour. Res., 46, W12536, doi:10.1029/2010WR009296.

Harr, R. D. (1977), Water flux in soil and subsoil on a steep forested slope, J. Hydrol., 33, 37-58.

Hewlett, J. D., and A. R. Hibbert (1967), Factors affecting the response of small watersheds to precipitation in humid areas, in Forest Hydrology, edited by W. E. Sopper and H. W. Lull, pp. 275-291, Pergamon Press, N. Y.

Hibbert, A. R. (1967), Forest treatment effects on water yield, in Proceedings of the International Symposium on Forest Hydrology, edited by W. E. Sopper and H. W. Lull, pp. 527-543, Pergamon, N. Y.

Hiemstra, C. A., G. E. Liston, and W. A. Reiners (2002), Snow Redistribution by Wind and Interactions with Vegetation at Upper Treeline in the Medicine Bow Mountains, Wyoming, U.S.A. Arctic, Antarctic, and Alpine Research, 34, No. 3, pp. 262-273.

Holdorf, H. D. (1981), Soil Resource Inventory, Lewis and Clark National Forest Interim In-Service Report, on file with the Lewis and Clark National Forest, Forest Supervisor's Office, Great Falls, MT.

Hopp, L., and J. J. McDonnell (2009), Connectivity at the hillslope scale: Identifying interactions between storm size, bedrock permeability, slope angle and soil depth, J. Hydrol., 376(3-4), 378-391, doi:10.1016/ j.jhydrol.2009.07.047.

Huff, D. D., R. V. O’Neill, W. R. Emanuel, J. W. Elwood, and J. D. Newbold (1982), Flow variability and hillslope hydrology, Earth Surf. Processes Landforms, 7(1), 91-94.

Iwagami, S., M. Tsujimura, O. Yuichi, J. Shimada, and T. Tanaka (2010), Role of bedrock groundwater in the rainfall-runoff process in a small headwater catchment underlain by volcanic rock, Hydrol. Processes, 24, 2771-2783, doi:10.1002/hyp.7690.

Jencso, K. G., B. L. McGlynn, M. N. Gooseff, S. M. Wondzell, K. E. Bencala, and L. A. Marshall (2009), Hydrologic connectivity between landscapes and streams: Transferring reach-and plot-scale understanding to the catchment scale, Water Resour. Res., 45, W04428, doi:10.1029/2008WR007225.

Jencso, K. G., B. L. McGlynn, M. N. Gooseff, K. E. Bencala, and S. M. Wondzell (2010), Hillslope hydrologic connectivity controls riparian groundwater turnover: Implications of catchment structure for riparian buffering and stream water sources, Water Resour. Res., 46, W10524, doi:10.1029/2009WR008818.

Kelliher, F. M., R. Leuning, and E.-D. Schulze (1993), Evaporation and canopy characteristics of coniferous forests and grasslands, Oecologia, 95(2), 153-163.

Komatsu, H. (2005), Forest categorization according to dry-canopy evaporation rates in a growing season: comparison of the Priestley-Taylor coefficient values from various observation sites, Hydrol. Process., 19, 3873-3896.

Lefsky, M. A., W. B. Cohen, G. G. Parker, and D. J. Harding (2002), Lidar remote sensing for ecosystem studies, Bioscience, 52(1), 19-30.

Leopold, L. B., and W. B. Langbein (1962), The concept of entropy in landscape evolution, U.S. Geol. Surv., Prof. Pap. 500A, pp. 1-20, Washington, D. C.

Leopold, L. B., M. G. Wolman, and J. P. Miller (1964), Fluvial Processes in Geomorphology, 522 pp., W.H. Freeman and Co., San Francisco, Calif.

Littell, J. S., D. McKenzie, D. L. Peterson, and A. L. Westerling (2009), Climate and wildfire area burned in western U.S. ecoprovinces, 19162003, Ecol. Appl., 19, 1003-1021.

Long, J. N., W. C. Schmidt, and J. L. Friede (compilers) (1996), T.W. Daniel Experimental Forest: Experimental forests, ranges, and watersheds in the Northern Rocky Mountains: A compendium of Outdoor Laboratories in Utah, Idaho, and Montana, pp., 31-36, USDA Forest Service Gen. Tech. Rep. INT-GTR-334

McGlynn, B. L., and J. J. McDonnell (2003a), Role of discrete landscape units in controlling catchment dissolved organic carbon dynamics, Water Resour. Res., 39(4), 18, 1090, doi:10.1029/2002WR001525.

McGlynn, B. L., and J. J. McDonnell (2003b), Quantifying the relative contributions of riparian and hillslope zones to catchment runoff, Water Resour. Res., 39(11), 20, 1310, doi:10.1029/2003WR002091.
McGlynn, B. L., and J. Seibert (2003), Distributed assessment of contributing area and riparian buffering along stream networks, Water Resour. Res., 39(4), 1082, 1082, doi:10.1029/2002WR001521.

McGlynn, B. L., J. J. McDonnell, J. Seibert, and C. Kendall (2004), Scale effects on headwater catchment runoff timing, flow sources, and groundwater-streamflow relations, Water Resour. Res., 40(7). W07504, doi:10.1029/2003WR002494.

McGuire, K. J., J. J. McDonnell, M. Weiler, C. Kendall, B. L. McGlynn, J. M. Welker, and J. Seibert (2005), The role of topography on catchment-scale water residence time, Water Resour. Res., 41, W05002, doi:10.1029/ 2004WR003657.

Mincemoyer, S. A., and J. L. Birdsall (2006), Vascular flora of the Tenderfoot Creek Experimental, Little Belt Mountains, Montana, MADRONO, 53(3), 211-222.

Montgomery, D. R., W. E. Dietrich, R. Torres, S. P. Anderson, J. T. Heffner, and K. Loague (1997), Hydrologic response of a steep, unchanneled valley to natural and applied rainfall, Water Resour. Res., 33(1), 91-109, doi:10.1029/96WR02985.

Mote, P. W., A. F. Hamlet, M. P. Clark, and D. P. Lettenmaier (2005), Declining Mountain Snowpack in Western North America*, Bull. Am. Meteorol. Soc., 86(1), 39-49.

Nobre, A. D., L. A. Cuartas, M. Hodnett, C. D. Rennó, G. Rodrigues, A. Silveira, M. Waterloo, and S. Saleska (2011), Height above the nearest drainage (HAND) - a hydrologically relevant new terrain model, $J$. Hydrol.,404, 13-29.

Ocampo, C. J., M. Sivapalan, and C. Oldham (2006), Hydrological connectivity of upland-riparian zones in agricultural catchments: Implications for runoff generation and nitrate transport, J. Hydrol., 331(3-4), 643658, doi:10.1016/j.jhydrol.2006.06.010.

Onda, Y., Y. Komatsu, M. Tsujimura, and J.-I. Fujihara (2001), The role of subsurface runoff through bedrock on storm flow generation, Hydrol. Processes, 15, 1693-1706.

Onda, Y., M. Tsujimura, J.-I. Fujihara, and I. Jun (2006), Runoff generation mechanisms in high-relief mountainous watersheds with different underlying geology, J. Hydrol., 331, 659-673, doi:10.1016/j.jhydrol.2006.06.009.

Pacific, V. J., K. G. Jencso, and B. L. McGlynn (2010), Variable flushing mechanisms and landscape structure control stream DOC export during snowmelt in a set of nested catchments, Biogeochemistry, 99(1-3), 193211, doi:10.1007/s10533-009-9401-1.

Payn, R. A., M. N. Gooseff, B. L. McGlynn, K. E. Bencala, and S. M. Wondzell (2011), Change from surface to subsurface control of spatial patterns in stream baseflow during a seasonal recession, Water Resour. Res., 45, W11427, doi:10.1029/2008WR007644.

Pederson, G. T., L. J. Graumlich, D. B. Fagre, T. Kipfer, and C. C. Muhlfeld (2009), A century of climate and ecosystem change in Western Montana: What do temperature trends portend?, Clim. Change, 98(1-2), 133-154.

Pomeroy, J. W., D. M. Gray, K. R. Shook, B. Toth, R. L. H. Essery, A. Pietroniro, and N. Hedstrom (1998), An evaluation of snow accumulation and ablation processes for land surface modeling, Hydrol. Process., 12, 2339-2367.

R Development Core Team (2008), R: A language and environment for statistical computing, R Foundation for Statistical Computing, Vienna, Austria, available at http://www.R-project.org.

Rennó, C. D., A. D. Nobre, L. A. Cuartas, J. V. Soares, M. G. Hodnett, J. Tomasella, and M. J. Waterloo (2008), HAND, a new terrain descriptor using SRTM-DEM: Mapping terra-firme rainforest environments in Amazonia, Remote Sens. Environ., 112, 3469-3481.

Reynolds, M. (1995), Geology of Tenderfoot Creek Experimental Forest, Little Belt Mountains, Meagher County, Montana, in Hydrologic and Geologic Characteristics of Tenderfoot Creek Experimental Forest, Montana, Final Rep. RJVA-INT-782 92734, edited by P. Farnes, Intermt. Res. Stn., For. Serv., U.S. Dept. of Agric., Bozeman, Mont.

Rinehart, A. J., E. R. Vivoni, and P. D. Brooks (2008), Effects of vegetation, albedo, and solar radiation sheltering on the distribution of snow in the Valles Caldera, New Mexico, Ecohydrol., 1(3), 253-270.

Savenije, H. H. G. (2010), HESS Opinions "Topography driven conceptual modelling (FLEX-Topo)," Hydrol. Earth Syst. Sci., 14, 2681-2692, doi:10.5194/hess-14-2681-2010.

Schmidt, K. M., and D. R. Montgomery (1995), Limits to relief, Science $270,617-620$.

Seibert, J., and B. L. McGlynn (2003), DEM-Based analysis of landscape organization: 2) Application to catchment comparison, Eos Trans. EGS AGU - EUG Joint Assembly Meeting Suppl., Nice, France, Abstract 9041.

Seibert, J., and B. L. McGlynn (2007), A new triangular multiple flow direction algorithm for computing upslope areas from gridded digital 
elevation models, Water Resour. Res., 43(4). W04501, doi:10.1029/ 2006WR005128.

Sidle, R. C., Y. Tsuboyama, S. Noguchi, I. Hosoda, M. Fujieda, and T. Shimizu (2000), Stormflow generation in steep forested headwaters: A linked hydrogeomorphic paradigm, Hydrol. Processes, 14(3), 369-385.

Soulsby, C., P. J. Rodgers, J. Petry, D. M. Hannah, I. A. Malcolm, and S. M. Dunn (2004), Using tracers to upscale flow path understanding in mesoscale mountainous catchments: Two examples from Scotland, $J$. Hydrol., 291(3-4), 174-196, doi:10.1016/j.jhydrol.2003.12.042.

Soulsby, C., D. Tetzlaff, P. Rodgers, S. Dunn, and S. Waldron (2006), Runoff processes, stream water residence times and controlling landscape characteristics in a mesoscale catchment: An initial evaluation, $J$. Hydrol., 325(1-4), 197-221, doi:10.1016/j.jhydrol.2005.10.024.

Tague, C., and G. E. Grant (2004), A geological framework for interpreting the low-flow regimes of Cascade streams, Willamette River Basin, Oregon, Water Resour. Res., 40, W04303, doi:10.1029/2003WR002629.

Tetzlaff, D., J. Seibert, K. J. McGuire, H. Laudon, D. A. Burn, S. M. Dunn, and C. Soulsby (2009), How does landscape structure influence catchment transit time across different geomorphic provinces?, Hydrol. Processes, 23(6), 945-953, doi:10.1002/hyp.7240.

Tóth, J. (1963), A theoretical analysis of groundwater flow in small drainage basins, J. Geophys. Res., 68, 4795-4812.

Tromp-van Meerveld, H. J., and J. J. McDonnell (2006), Threshold relations in subsurface stormflow 1. A 147 storm analysis of the Panola hillslope, Water Resour. Res., 42, W02410, doi:10.1029/2004WR003778.

Tromp-van Meerveld, H. J., N. E. Peters, and J. J. McDonnell (2007), Effect of bedrock permeability on subsurface stormflow and the water balance of a trenched hillslope at the Panola Mountain Research Watershed, Georgia, USA, Hydrol. Processes 21, 750-769.

Varhola, A., N. Coops, M. Weiler, and R. D. Moore (2010), Forest canopy effects on snow accumulation and ablation: An integrative review of empirical results, J. Hydrol., 392, 219-233, doi:10.1016/j.jhydrol.2010.08.009.
Vidon, P. G. F., and A. R. Hill (2004), Landscape controls on the hydrology of stream riparian zones, J. Hydrol., 292(1-4), 210-228, doi:10.1016/ j.jhydrol.2004.01.005.

Vose, J. M., G. Sun, C. R. Ford, M. Bredemeier, K. Otsuki, X. Wei, Z. Zhang, and L. Zhang (2011), Forest ecohydrological research in the 21st century: What are the critical needs?, Ecohydrol., 4(2), 146-158.

Wagener, T., M. Sivapalan, P. Troch, and R. Woods (2007), Catchment classification and hydrologic similarity, Geography Compass, 1, 901931, doi:10.1111/j.1749-8198.2007.00039.x.

Westerling, A. L., H. G. Hidalgo, D. R. Cayan, and T. W. Swetnam (2006), Warming and earlier spring increase western U.S. forest wildfire activity, Science, 313(5789), 940-943.

Western, A. W., R. B. Grayson, G. Blöschl, G. R. Willgoose, and T. A. McMahon (1999), Observed spatial organization of soil moisture and its relation to terrain indices, Water Resour. Res., 35(3), 797-810, doi:10.1029/1998WR900065.

Wolock, D. M., J. Fan, and G. B. Lawrence (1997), Effects of basin size on low-flow stream chemistry and subsurface contact time in the Neversink River watershed, New York, Hydrol. Processes, 11, 1273-1286.

Woods, R., and L. Rowe (1996), The changing spatial variability of subsurface flow across a hillside, J. Hydrol., 35, 51-86.

Woods, S. W., R. Ahl, J. Sappington, and W. W. McCaughey (2006), Snow accumulation in thinned lodgepole pine stands, Montana, USA, J. Forest Ecol., 235, 202-211, doi:10.1016/j.foreco.2006.08.013.

Yetemen, O., E. Istanbulluoglu, and E. R. Vivoni (2010), The implications of geology, soils, and vegetation on landscape morphology: Inferences from semi-arid basins with complex vegetation patterns in Central New Mexico, USA, Geomorphology, 116(3-4), 246-263.

K. G. Jencso and B. L. McGlynn, Department of Land Resources and Environmental Sciences, Montana State University, 334 Leon Johnson Hall, Boseman, MT 59717, USA. (kelseyjencso@gmail.com) 